\title{
Stratospheric ozone change and related climate impacts over 1850-2100 as modelled by the ACCMIP ensemble
}

\author{
F. Iglesias-Suarez, P. J. Young, and O. Wild \\ Lancaster Environment Centre, Lancaster University, Lancaster, UK \\ Correspondence to: F. Iglesias-Suarez (n.iglesiassuarez@lancaster.ac.uk)
}

Received: 3 July 2015 - Published in Atmos. Chem. Phys. Discuss.: 15 September 2015

Revised: 10 December 2015 - Accepted: 11 December 2015 - Published: 18 January 2016

\begin{abstract}
Stratospheric ozone and associated climate impacts in the Atmospheric Chemistry and Climate Model Intercomparison Project (ACCMIP) simulations are evaluated in the recent past (1980-2000), and examined in the longterm (1850-2100) using the Representative Concentration Pathways (RCPs) low- and high-emission scenarios (RCP2.6 and RCP8.5, respectively) for the period 2000-2100. ACCMIP multi-model mean total column ozone (TCO) trends compare favourably, within uncertainty estimates, against observations. Particularly good agreement is seen in the Antarctic austral spring $\left(-11.9 \% \mathrm{dec}^{-1}\right.$ compared to observed $\sim-13.9 \pm 10.4 \% \mathrm{dec}^{-1}$ ), although larger deviations are found in the Arctic's boreal spring $\left(-2.1 \% \mathrm{dec}^{-1}\right.$ compared to observed $\sim-5.3 \pm 3.3 \% \mathrm{dec}^{-1}$ ). The simulated ozone hole has cooled the lower stratosphere during austral spring in the last few decades $\left(-2.2 \mathrm{~K} \mathrm{dec}^{-1}\right)$. This cooling results in Southern Hemisphere summertime tropospheric circulation changes captured by an increase in the Southern Annular Mode (SAM) index $\left(1.3 \mathrm{hPa} \mathrm{dec}^{-1}\right)$. In the future, the interplay between the ozone hole recovery and greenhouse gases (GHGs) concentrations may result in the SAM index returning to pre-ozone hole levels or even with a more positive phase from around the second half of the century ( -0.4 and $0.3 \mathrm{hPa} \mathrm{dec}^{-1}$ for the RCP2.6 and RCP8.5, respectively). By 2100 , stratospheric ozone sensitivity to GHG concentrations is greatest in the Arctic and Northern Hemisphere midlatitudes (37.7 and 16.1 DU difference between the RCP2.6 and RCP8.5, respectively), and smallest over the tropics and Antarctica continent (2.5 and 8.1 DU respectively). Future TCO changes in the tropics are mainly determined by the upper stratospheric ozone sensitivity to GHG concentrations, due to a large compensation between tropospheric and lower stratospheric column ozone changes in the
\end{abstract}

two RCP scenarios. These results demonstrate how changes in stratospheric ozone are tightly linked to climate and show the benefit of including the processes interactively in climate models.

\section{Introduction}

The Atmospheric Chemistry and Climate Model Intercomparison Project (ACCMIP) (Lamarque et al., 2013b) was designed to evaluate the long-term (1850-2100) atmospheric composition changes (e.g. ozone) to inform the Fifth Assessment Report of the Intergovernmental Panel on Climate Change (IPCC, 2013), supplementing phase 5 of the Coupled Model Intercomparison Project (CMIP5) (Taylor et al., 2012), where the focus was more on physical climate change. In addition, ACCMIP is the first model intercomparison project in which the majority of the models included chemical schemes appropriate for stratospheric and tropospheric chemistry. Due to the absorption of shortwave radiation, stratospheric ozone is important for determining the stratospheric climate (e.g. Randel and Wu, 1999) and has a strong influence on tropospheric ozone through stratosphereto-troposphere transport (e.g. Collins et al., 2003; Sudo et al., 2003; Zeng and Pyle, 2003). In addition, changes in stratospheric ozone can affect atmospheric circulation and climate, reaching to the lower troposphere in the case of the Antarctic ozone hole (e.g. Thompson and Solomon, 2002; Gillett and Thompson, 2003). This study evaluates stratospheric ozone changes and associated climate impacts in the ACCMIP simulations, quantifying the evolution since the pre-industrial period through to the end of the 21 st century. 
Stratospheric ozone represents approximately $90 \%$ of ozone in the atmosphere and absorbs much of the ultraviolet solar radiation harmful for the biosphere (e.g. WMO, 2014; UNEP, 2015). Anthropogenic emissions of ozone-depleting substances (ODS) such as chlorofluorocarbons and other halogenated compounds containing chlorine and bromine have played a key role in depleting stratospheric ozone during the latter half of the 20th century (e.g. WMO, 2014). Although present globally averaged TCO levels are only $\sim 3.5 \%$ lower than pre-1980 values, about half the TCO is depleted over Antarctica between September and November (austral spring) each year (Forster et al., 2011). Globally, halogen loading peaked around 1998 (although this depends on altitude and latitude) and started to decrease afterwards due to the implementation of the Montreal Protocol and its Amendments and Adjustments (e.g. WMO, 2007, 2014). As a result, stratospheric ozone is expected to recover and return to pre-industrial values during the 21st century (e.g. Austin and Wilson, 2006; Eyring et al., 2010a). Although anthropogenic ODS are the main cause of ozone depletion over the last decades, other species such as methane, nitrous dioxide $\left(\mathrm{N}_{2} \mathrm{O}\right)$, and carbon dioxide $\left(\mathrm{CO}_{2}\right)$ affect stratospheric ozone chemistry as well (e.g. Haigh and Pyle, 1982; Portmann et al., 2012; Revell et al., 2012; Reader et al., 2013). Randeniya et al. (2002) argued that increasing concentrations of methane can amplify ozone production in the lower stratosphere via photochemical production, though increases of water vapour from methane oxidation may have the opposite effect (Dvortsov and Solomon, 2001). Nitrogen oxides $\left(\mathrm{NO}_{x}\right)$ chemistry is important in the middle-upper stratosphere for ozone; thus, variations and trends in the source gas $\left(\mathrm{N}_{2} \mathrm{O}\right)$ may have a substantial influence on ozone levels (e.g. Ravishankara et al., 2009; Portmann et al., 2012; Revell et al., 2012).

As ODS levels slowly decrease, projected climate change will likely play a key role in stratospheric ozone evolution through its impacts on temperature and atmospheric circulation (e.g. IPCC, 2013). The impact of climate change on ozone in the stratosphere further complicates the attribution of the recovery (e.g. Waugh et al., 2009a; Eyring et al., 2010b) since increases in $\mathrm{CO}_{2}$ levels cool the stratosphere, slowing gas-phase ozone loss processes (e.g. reduced $\mathrm{NO}_{x}$ abundances; reduced $\mathrm{HO}_{x}$-catalysed ozone loss; and enhanced net oxygen chemistry) resulting in ozone increases, particularly in the middle-upper stratosphere and high latitudes (e.g. Haigh and Pyle, 1982; Randeniya et al., 2002; Rosenfield et al., 2002). Further, an acceleration of the equator-to-pole Brewer-Dobson circulation (BDC) has been predicted in many model studies under high GHG concentrations (e.g. Butchart et al., 2006, 2010; Garcia and Randel, 2008), although its strength can only be inferred indirectly from observations, meaning that there are large uncertainties in recent trends (e.g. Engel et al., 2009; Bönisch et al., 2011; Young et al., 2011; Stiller et al., 2012). This BDC acceleration enhances transport in the atmosphere and stratospheric- tropospheric exchange (STE), and is likely to have a substantial role throughout the 21st century (e.g. Butchart, 2014). STE is a key transport process that links ozone in the stratosphere and the troposphere (e.g. Holton et al., 1995), characterized by downward flux of ozone-rich stratospheric air, mainly at mid-latitudes, and upward transport of ozone-poor tropospheric air in tropical regions. In contrast, ozone loss cycles could increase with higher $\mathrm{N}_{2} \mathrm{O}$ and lower methane concentrations (e.g. Randeniya et al., 2002; Ravishankara et al., 2009).

Traditionally, chemistry-climate models (CCMs) have been used to produce stratospheric ozone projections into the past and the future (e.g. WMO, 2007, 2014), usually prescribing sea surface temperatures and sea-ice concentrations from observations or climate simulations. Some coordinated climate model experiments, such as the CMIP5 and the Chemistry-Climate Model Validation activities (CCMVal and CCMVal2) (Eyring et al., 2006, 2007, 2010a, 2013; Austin et al., 2010) have examined stratospheric ozone evolution. Recent past stratospheric column ozone projections ( 1960-2000), from the above coordinated climate model experiments, show substantial decreases driven mainly by anthropogenic emissions of ODS and agree well with observations. However, future stratospheric ozone projections are influenced by both the slow decrease in ODS levels and the climate scenario chosen. To illustrate this, Eyring et al. (2013) used a subgroup of CMIP5 models with interactive chemistry in the stratosphere and the troposphere to show gradual recovery of ozone levels during the next decades (as ODS abundances decrease in the stratosphere), and global multi-model mean stratospheric column ozone "super-recovery" (higher levels than those projected in the pre-ozone depletion period) for the most pessimistic emission scenario (RCP8.5) at the end of the 21st century. A main recommendation from the SPARC-CCMVal (2010) report is that CCMs should keep developing towards self-consistent stratosphere-troposphere chemistry, interactively coupled to the dynamics and radiation (e.g. enabling chemistry-climate feedbacks).

Tropospheric ozone accounts for the remaining $\sim 10 \%$ atmospheric ozone, where it is a GHG, a pollutant with significant negative effects to vegetation and human health, and a main source of hydroxyl radicals controlling the oxidizing capacity of the atmosphere (e.g. Prather et al. 2001; Gregg et al., 2003; Jerrett et al., 2009). Its abundance in the troposphere is determined from the balance of STE and photochemistry production involving the oxidation of hydrocarbons and carbon monoxide (CO) in the presence of $\mathrm{NO}_{x}$, versus chemical destruction and deposition to the surface (e.g. Lelieveld and Dentener, 2000; Wild, 2007). These terms depend in turn on climate system dynamics (e.g. STE) and on the magnitude and spatial distribution of ozone precursors emissions such as volatile organic compounds, $\mathrm{NO}_{x}$, and $\mathrm{CO}$ (e.g. chemical production and destruction) (e.g. Wild, 2007). Several studies found tropospheric ozone increases due to 
climate change via enhanced STE (e.g. Collins et al., 2003; Sudo et al., 2003; Zeng and Pyle, 2003). Other studies have shown a positive relationship between anthropogenic emissions and tropospheric ozone abundance (e.g. Stevenson et al., 2006; Young et al., 2013a). However, the ultimately net impact of climate and emissions changes remains unclear (Stevenson et al., 2006; Isaksen et al., 2009; Jacob and Winner, 2009), and it may differ substantially by region, altitude, or season (e.g. Myhre et al., 2013).

Further, the ozone hole influences surface climate via temperature and circulation changes (e.g. Thompson and Solomon, 2002; Gillett and Thompson, 2003) owing to direct radiative effects (e.g. Randel and Wu, 1999; Forster et al., 2011). The ozone layer heats the stratosphere by absorbing incoming ultraviolet solar radiation, hence, trends and variations on ozone would impact stratospheric dynamics (e.g. Ramaswamy et al., 2006; Randel et al., 2009; Gillett et al., 2011). In the Southern Hemisphere (SH), stratospheric circulation changes associated to ozone depletion have been linked to tropospheric circulation changes primarily during austral summer (lagging the former 1-2 months), based on observations (Thompson and Solomon, 2002) and model simulations (Gillett and Thompson, 2003). These SH extratropical circulation changes could be described by the leading mode of variability or the SAM (e.g. Thompson and Wallace, 2000). Previous studies based on CCMs simulations reported positive trends in the SAM over the ozone depletion period (e.g. Sexton, 2001; Shindell and Schmidt, 2004; Arblaster and Meehl, 2006; Polvani et al., 2010; McLandress et al., 2011). Furthermore, some modelling studies have projected a poleward shift (i.e. positive change) in the SAM due to future increases in GHGs (e.g. Fyfe et al., 1999; Marshall et al., 2004). Projected ozone recovery should have the opposite effect than ozone depletion (i.e. a negative trend in the SAM), and this is important as it opposes the effect of increasing GHG concentrations. Some studies suggest that these effects will largely cancel out each other during the next several decades in austral summer owing to these competing forces (e.g. Perlwitz et al., 2008; Son et al., 2009; Arblaster et al., 2011; Polvani et al., 2011; Barnes et al., 2013; Gillett and Fyfe, 2013).

Multi-model experiments are useful for evaluating model differences in not fully understood processes and associated feedbacks, and for identifying agreements and disagreements between various parameterizations (e.g. Shindell et al., 2006; Stevenson et al., 2006). While CMIP5 provides a framework towards a more Earth System approach to intercompare model simulations and enables their improvement, it lacks comprehensive information on atmospheric composition and models with full interactive chemistry (Lamarque et al., 2013b). ACCMIP aims to fill this gap by evaluating how atmospheric composition drives climate change, and provides a gauge of the uncertainty by different physical and chemical parameterizations in models (Myhre et al., 2013). In this study we quantify the evolution of stratospheric ozone and related climate impacts in the ACCMIP simulations from pre-industrial times (1850), recent past (1980) and present day (2000) to the near-future (2030) and the end of the 21st century (2100). First, we evaluate recent past and present-day ACCMIP stratospheric ozone simulations with observations and other model-based products. Then, we assess ozone projections and ozone sensitivity to GHG concentrations. Finally, a description of the associated impacts of stratospheric ozone depletion and projected recovery in the climate system is presented, with a focus in the SH. In addition, this study compares ACCMIP simulations with those from CMIP5 and CCMVal2 and identifies agreements and disagreements among different parameterizations. This paper complements previous analysis of the ACCMIP simulations on tropospheric ozone evolution (Young et al., 2013a; Parrish et al., 2014), radiative forcing (Bowman et al., 2013; Shindell et al., 2013a; Stevenson et al., 2013), hydroxyl radical and methane lifetime (Naik et al., 2013b; Voulgarakis et al., 2013), historical black carbon evaluation (Lee et al., 2013), nitrogen and sulfur deposition (Lamarque et al., 2013a), and climate evaluation (Lamarque et al., 2013b).

The remainder of this paper is organized as follows. Section 2 describes the models and simulations used here, with a focus on the various ozone chemistry schemes. In Sect. 3, ozone is examined in the recent past against observations, and analysed from 1850 to 2100 under the low and high RCPs emission scenarios for those models with interactive chemistry-climate feedback. Section 4 explores past and future stratospheric ozone evolution and climate interactions. A discussion of the results is presented in Sect. 5, followed by a brief summary and main conclusions in Sect. 6 .

\section{Models, simulations, and analysis}

In this section we describe main details of the ACCMIP models, simulations, and analyses conducted in this paper. A comprehensive description of the models and simulations along with further references are provided by Lamarque et al. (2013b).

\subsection{ACCMIP models}

Table 1 summarizes the ACCMIP models analysed in this study and their important features. We considered eight models that had time-varying stratospheric ozone, either prescribed (offline) or interactively calculated (online). From the full ACCMIP ensemble (Lamarque et al., 2013b), we have excluded the following: EMAC, GEOSCCM and GISSE2-TOMAS, as these did not produce output for all the scenarios and time periods analysed here (see Sect. 2.2); CICERO-OsloCTM and LMDzORINCA, as these used a constant climatological value of stratospheric ozone; MOCAGE and STOC-HadAM3, which showed poor stratospheric ozone chemistry performance compared to observa- 
Table 1. Summary of the ACCMIP models used here.

\begin{tabular}{|c|c|c|c|c|}
\hline Model & $\begin{array}{l}\text { Stratospheric } \\
\text { ozone }\end{array}$ & $\begin{array}{l}\text { Composition-radiation } \\
\text { coupling }\end{array}$ & $\begin{array}{l}\text { Photolysis } \\
\text { scheme }\end{array}$ & Reference \\
\hline CESM-CAM-superfast & CHEM & Yes & Adjusted look-up table & Lamarque et al. (2012) \\
\hline CMAM & CHEM & Yes & Adjusted look-up table & Scinocca et al. (2008) \\
\hline GFDL-AM3 & CHEM & Yes & Adjusted look-up table & Donner et al. (2011), Naik et al. (2013a) \\
\hline GISS-E2-R & CHEM & Yes & Online & Koch et al. (2006), Shindell et al. (2013b) \\
\hline HadGEM2 & NOCHEM & Yes & Look-up table & Collins et al. (2011) \\
\hline MIROC-CHEM & CHEM & Yes & Online & Watanabe et al. (2011) \\
\hline NCAR-CAM3.5 & CHEM & Yes & Adjusted look-up table & Lamarque et al. $(2011,2012)$ \\
\hline UM-CAM & NOCHEM & No & Look-up table & Zeng et al. $(2008,2010)$ \\
\hline
\end{tabular}

tions; and NCAR-CAM5.1, as this model was focused on aerosol output and did not save ozone fields.

The ACCMIP models included in this study are CCMs (7) or chemistry general circulation models (1) with atmospheric chemistry modules. The CCMs implemented a coupled composition-radiation scheme, whereas the chemistry and radiation was not coupled in UM-CAM (see Table 1). Both sea surface temperatures and sea-ice concentrations were prescribed, except in GISS-E2-R which interactively calculated them. Similarly to Eyring et al. (2013), we group the models into two categories: six models with full atmospheric chemistry (CHEM), and two models with online tropospheric chemistry but with prescribed ozone in the stratosphere (NOCHEM) (Fig. 4 of Lamarque et al., 2013b). All CHEM models included ODS (with $\mathrm{Cl}$ and $\mathrm{Br}$ ) and the impact of polar stratospheric clouds (PSCs) on heterogeneous chemistry, although a linearized ozone chemistry parameterization was implemented in CESM-CAMSuperfast (McLinden et al., 2000; Hsu and Prather, 2009). The other two models, HadGEM2 and UM-CAM, prescribed stratospheric ozone concentrations from the IGAC/SPARC database (Cionni et al., 2011).

A final important distinction among the models is how stratospheric changes are able to influence photolysis rates. The simplest scheme is for HadGEM2 and UM-CAM, where the photolysis rates are derived from a look-up table as a function of time, latitude, and altitude only, and using a climatological cloud and ozone fields (i.e. the rates are the same for all simulations) (e.g. Zeng et al., 2008, 2010; Collins et al., 2011; The HadGEM2 Development Team, 2011). The look-up table is more complex with CESM-CAM-Superfast (Gent et al., 2010), CMAM (Scinocca et al., 2008), GFDLAM3 (Donner et al., 2011; Griffies et al., 2011), and NCARCAM3.5 (Gent et al., 2010; Lamarque et al., 2012), where an adjustment is applied to take surface albedo and cloudiness into account, which couples with the simulated aerosols. Fully online photolysis calculations were only made for MIROC-CHEM (Watanabe et al., 2011) and GISS-E2-R (Schmidt et al., 2006; Shindell et al., 2013b).

As per Young et al. (2013a), all models were interpolated to a common grid $\left(5^{\circ}\right.$ by $5^{\circ}$ latitude/longitude and 24 pressure levels).

\subsection{ACCMIP scenarios and simulations}

The ACCMIP simulations were designed to span the preindustrial period to the end of the 21 st century. In this study, time slices from the years 1850, 1980, and 2000 comprise historical projections (hereafter Hist), whereas time slices from the years 2030 and 2100 comprise future simulations. The latter follow the climate and composition and/or emission projections prescribed by the RCPs (van Vuuren et al., 2011; Lamarque et al., 2012), named after their nominal radiative forcing at the end of the 21 st century relative to 1750. Here we consider RCP2.6 (referring to $2.6 \mathrm{Wm}^{-2}$ ) and RCP8.5 $\left(8.5 \mathrm{Wm}^{-2}\right)$, since they bracket the range of warming in the ACCMIP simulations, and are the scenarios that have been completed by the greatest number of models.

Future ODS (the total organic chlorine and bromine compounds) in CHEM models follow the RCPs values from Meinshausen et al. (2011), which does not include the early phase-out of hydrochlorofluorocarbons agreed in 2007 by the Parties to the Montreal Protocol. Note that ODS may be specified as concentrations (CMAM, GFDL-AM3 and NCARCAM3.5) or emissions (CESM-CAM-superfast, GISS-E2-R, MIROC-CHEM) in different models, though these were the same within each time slice simulation (except for GISSE2-R; see below). No significant trends are found for stratospheric ozone in those years that form part of the Hist 1980 time slice for the latter models, even though ODS were specified as emissions (i.e. any trends in ODS concentration in the stratosphere due to transport timescales do not significantly affect ozone concentrations). This is slightly different from the modified halogen scenario of WMO (2007) used in the IGAC/SPARC ozone database employed by the NOCHEM models. Nevertheless, halogen concentrations in both future scenarios peak around the year 2000 and decline afterwards, although slightly different timing of ozone returning to historical levels may be found. Tropospheric ozone precursors emissions follow Lamarque et al. (2010) for the historical period, and Lamarque et al. (2013b) for the RCPs.

Most models completed time slice simulations for each period and scenario, usually 10 years average for each time slice (e.g. 1975-1984 for the Hist 1980 time slice, although other models simulated time slices ranging from 5 to 
11 years). Notice that interannual variability for a given time slice is generally small (Young et al., 2013a). The exception is GISS-E2-R, which ran transient simulations with a coupled ocean. Equivalent time slice means were calculated by averaging 10 years centred on the desired time slice, (19751984 for 1980 and so forth), except for the 1850 and 2100 time slices (e.g. 1850-1859 mean).

\subsection{CMIP5 and CCMVal2 simulations}

We also include CMIP5 and CCMVal2 simulations as a benchmark for the former models. We use a subset of five "high" top CMIP5 models, defined here as those models that represented and saved ozone output above $10 \mathrm{hPa}$ for the historical (1850-2005, most of the models) and future (RCP2.6 and RCP8.5, 2005-2100) emission scenarios: CESM1-WACCM, GFDL-CM3, MPI-ESM-LR, MIROCESM, and MIROC-ESM-CHEM. Only high top models are considered here due to the implications the upper stratosphere has on, among other factors, stratospheric dynamical variability (Charlton-Perez et al., 2013), and tropospheric circulation (Wilcox et al., 2012). Moreover, we will show how, in the tropics, upper stratospheric ozone plays a key role on TCO projections during the 21 st century (see Sect. 3.2). Again, we group the models into two categories: three models with full atmospheric chemistry (CHEM: CESM1WACCM, GFDL-CM3 and MIROC-ESM-CHEM), and two models with prescribed ozone (NOCHEM: MPI-ESM-LR and MIROC-ESM). A detailed description of the models, simulations, and ozone concentrations is presented by Taylor et al. (2012) and Eyring et al. (2013).

In addition, we include $14 \mathrm{CCMVal} 2$ models that represented ozone under the REF-B1 scenario (1960-2006, most of the models): CAM3.5, CCSRNIES, CMAM, E39CA, EMAC, GEOSCCM, LMDZrepro, Niwa-SOCOL, SOCOL, ULAQ, UMETRAC, UMUKCA-METO, UMUKCAUCAM, and WACCM. All these models had interactive stratospheric chemistry and coupled composition-climate feedback, although simplified or absent chemistry in the troposphere. Morgenstern et al. (2010b) describe in detail CCMVal2 models and REF-B1 simulations.

In contrast to ACCMIP time slice simulations, these data sets were based on transient experiments, which may result in slightly different ozone levels, as simulations depart from initial conditions. Nevertheless, equivalent time slice means were calculated in the same manner as above for consistency purposes throughout all analysis involving trends or ozone changes. A caveat is that TCO was calculated from the ozone mixing ratio field, which may slightly differ $(\sim 1.5 \%)$ from that of the model's native TCO (Eyring et al., 2013).

\subsection{Tropopause definition}

For the purpose of comparing the outputs among models, a tracer tropopause definition has been argued to be suit- able (Wild, 2007). This study follows Young et al. (2013a) method, in which the tropopause is based on the $150 \mathrm{ppbv}$ ozone contour, after Prather et al. (2001). The definition is fitted for all time slices using ozone from the Hist 1850 time slice for each model and month; meaning that the "troposphere" is defined as a fixed volume region of the atmosphere. On the one hand, Young et al. (2013a) argued that using a monthly mean tropopause from the 1850 time slice prevents issues with different degrees of ozone depletion among the models, especially for $\mathrm{SH}$ high latitudes. On the other hand, this neglects the fact that the tropopause height may vary with time due to climate change (e.g. Santer et al., 2003a, b). Nevertheless, Young et al. (2013a) have shown that using ozone from the Hist 2000 time slice to define the tropopause across all time slices, generally results in tropospheric ozone columns of $\pm 5 \%$ compared to the Hist 1850 time slice.

\subsection{Trend calculations}

The different data sets trends are broadly comparable but differ slightly in their calculation and uncertainty determination. For ACCMIP, CMIP5, and CCMVal2 models, the trends are for the differences between the Hist 1980 and 2000 time slices with the range shown as box and/or whisker plots (central $50 \%$ of trends as the box; $95 \%$ confidence intervals as the whiskers). Note that using time slices to calculate trends will underestimate the uncertainty from interannual variability. However, least squares linear trends calculated for CMIP5 and CCMVal2 models (i.e. between 1980 and 2000) are similar to those calculated from differences between time slices.

Trends for observational estimates and ozone databases (used in Sects. 3.1 and 4) are least squares linear trends (i.e. between 1980 and 2000 for consistency reasons with time slices), with error bars indicating the $95 \%$ confidence level based on the standard error for the fit, and corrected for lag-1 autocorrelation for the former (Santer et al., 2000).

\section{Long-term total column ozone evolution in the ACCMIP models}

This section presents an evaluation of the present-day (Hist 2000) TCO distribution and recent (1980-2000) ozone trends against observations and observationally derived data. The evolution of TCO from the pre-industrial period (1850) to the end of the 21 st century (2100) is also discussed, with a particular focus on the different contribution of trends in the tropical tropospheric, lower stratospheric, and upper stratospheric columns to the total column trend. Previously, Young et al. (2013a) have shown that TCO distribution changes in the ACCMIP multi-model mean agree well with the Total Ozone Mapping Spectrometer (TOMS) for the last few decades (their Fig. S7). However, ACCMIP models simu- 

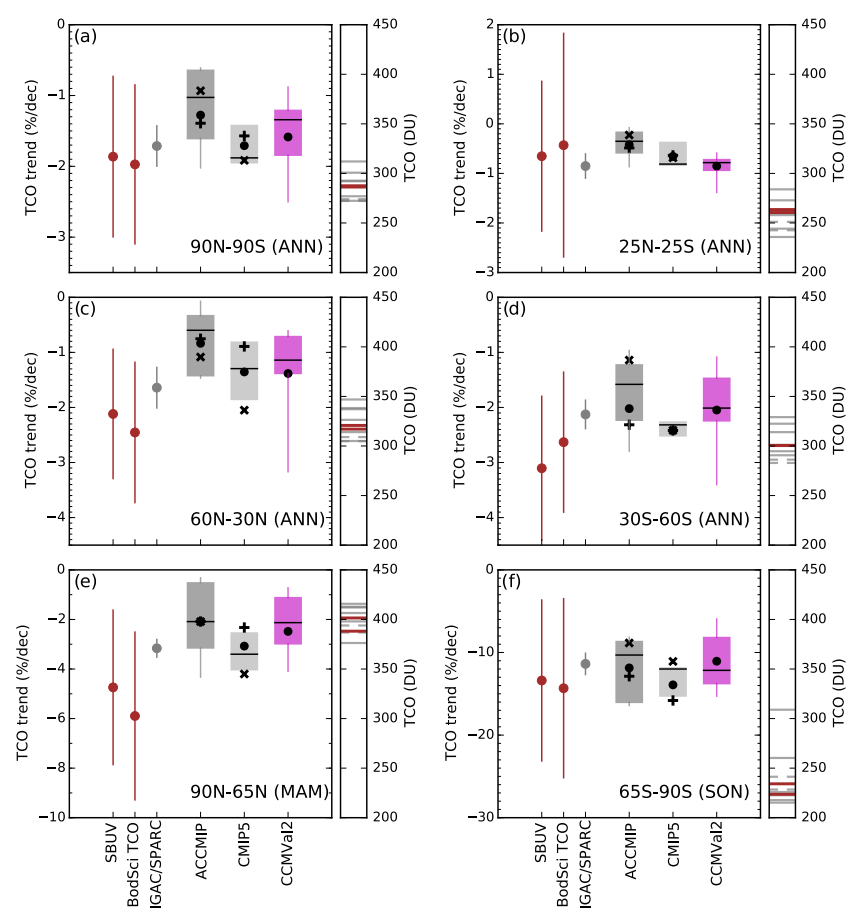

— SBUV / BodSCI TCO — ACCMIP CHEM

ACCMIP NOCHEM

Figure 1. Total column ozone trends from 1980 to $2000\left(\% \mathrm{dec}^{-1}\right)$ for the annual mean (ANN) (a) global, (b) in the tropics, (c) in the northern midlatitudes, (d) in the southern midlatitudes, (e) for the boreal spring in the Arctic (MAM), and (f) for austral spring in the Antarctic (SON). The box, whiskers, and line indicate the interquartile range, $95 \%$ range and median respectively, for the ACCMIP (light grey), CMIP5 (dark grey), and CCMVal2 (magenta) models. Multi-model means are indicated by dots. CHEM (models with interactive chemistry) and NOCHEM (models that prescribe ozone) means are indicated by "plus" and "cross" symbols, respectively. Observations and IGAC/SPARC data sets are represented by error bars indicating the $95 \%$ confidence intervals (one tail).

late weaker (not significant) ozone depletion in early boreal spring over the Arctic between Hist 1980 and 2000 compared to TOMS (see also Sects. 3.1 and 5).

\subsection{Evaluation of ozone trends, 1980-2000}

Figure 1 shows TCO decadal trends between 1980 and 2000 for the global mean, and a number of latitude bands. The figure compares the ACCMIP, CMIP5, and CCMVal2 models against the Bodeker Scientific TCO data set (BodSci TCO version 2.8), combining a number of different satellite-based instruments (Bodeker et al., 2005; Struthers et al., 2009), and observations from the Solar Backscatter Ultraviolet (SBUV - version 8.6) merged ozone data set (McPeters et al., 2013). In addition, Fig. 1 includes trends from the IGAC/SPARC ozone data set (Cionni et al., 2011) which was used by the majority of the models with prescribed ozone concentrations (both ACCMIP and CMIP5). The annual mean is used in evaluations for the global, tropical, and midlatitude regions. Additional evaluations are made for the boreal spring in the Arctic (March, April and May) and the austral spring in the Antarctic (September, October and November) when strongest ozone depletion occurs.

Within uncertainty, the overall response for ACCMIP is in good agreement with observational data sets in terms of decadal trends and absolute values, with the Northern Hemisphere $(\mathrm{NH})$ being the region where models differ most. These results also compare favourably with those reported by WMO (2014). In line with CMIP5 and CCMVal2 models, strongest changes are found over Antarctica in austral spring associated to the ozone hole, and smallest over the tropics where ODS are least effective. ACCMIP NOCHEM models typically simulate smaller decadal trends than CHEM models, consistent with the possible underestimation of SH ozone depletion trends in the IGAC/SPARC ozone data set (Hassler et al., 2013; Young et al., 2014). However, outside extratropical SH regions, IGAC/SPARC ozone data set (i.e. used to drive the majority of ACCMIP and CMIP5 NOCHEM models) tends to show better agreement with observations than CHEM models. ACCMIP CHEM and CMIP5 CHEM models show very similar TCO decadal trends in all regions $\left( \pm 0.1-0.2 \% \mathrm{dec}^{-1}\right)$, although differing somewhat more at high latitudes in the $\mathrm{SH}$, where ozone depletion is greatest $\left( \pm 2.9 \% \mathrm{dec}^{-1}\right)$. ACCMIP NOCHEM and CMIP5 NOCHEM models show more disparate trends $\left( \pm 0.5-2.1 \% \mathrm{dec}^{-1}\right)$, which may be related to different ozone data sets and the implementation method on each model (i.e. online tropospheric chemistry in ACCMIP models).

Figure 2 compares vertically resolved ozone decadal trends for the same period, regions, and seasons, for the ACCMIP multi-model mean and individual models against the Binary Database of Profiles (BDBP version 1.1.0.6) data set, using the so-called Tier 0 and Tier 1.4 data (Bodeker et al., 2013). Tier 0 includes ozone measurements from a wide range of satellite and ground-based platforms, whereas Tier 1.4 is a regression model fitted to the same observations. Uncertainty estimates for the BDBP Tier 1.4 trends are from the linear least square fits, as for the observations in Fig. 1. ACCMIP shows most disagreement with the BDBP data in the lower and middle stratosphere region and best agreement with Tier 1.4 in the upper stratosphere.

In the Tropics (Fig. 1b), TCO in all data sets agrees fairly well with observations. Although ACCMIP, CMIP5, and CCMVal 2 simulate small decadal trends $(-0.4,-0.7$ and $-0.9 \% \mathrm{dec}^{-1}$ respectively), the spread of the models at the $95 \%$ confidence interval stays within the negative range. However, uncertainty estimates in TCO in the SBUV and BodSci TCO data sets embrace trends of different signs $\left(-0.7 \pm 1.5 \% \mathrm{dec}^{-1}\right.$, and $-0.4 \pm 2.3 \% \mathrm{dec}^{-1}$ respectively). IGAC/SPARC presents slightly larger negative decadal trends than observations in this region. CMIP5 CHEM and CCMVal2 multi-model means show slightly stronger decadal trends than ACCMIP CHEM models in this 

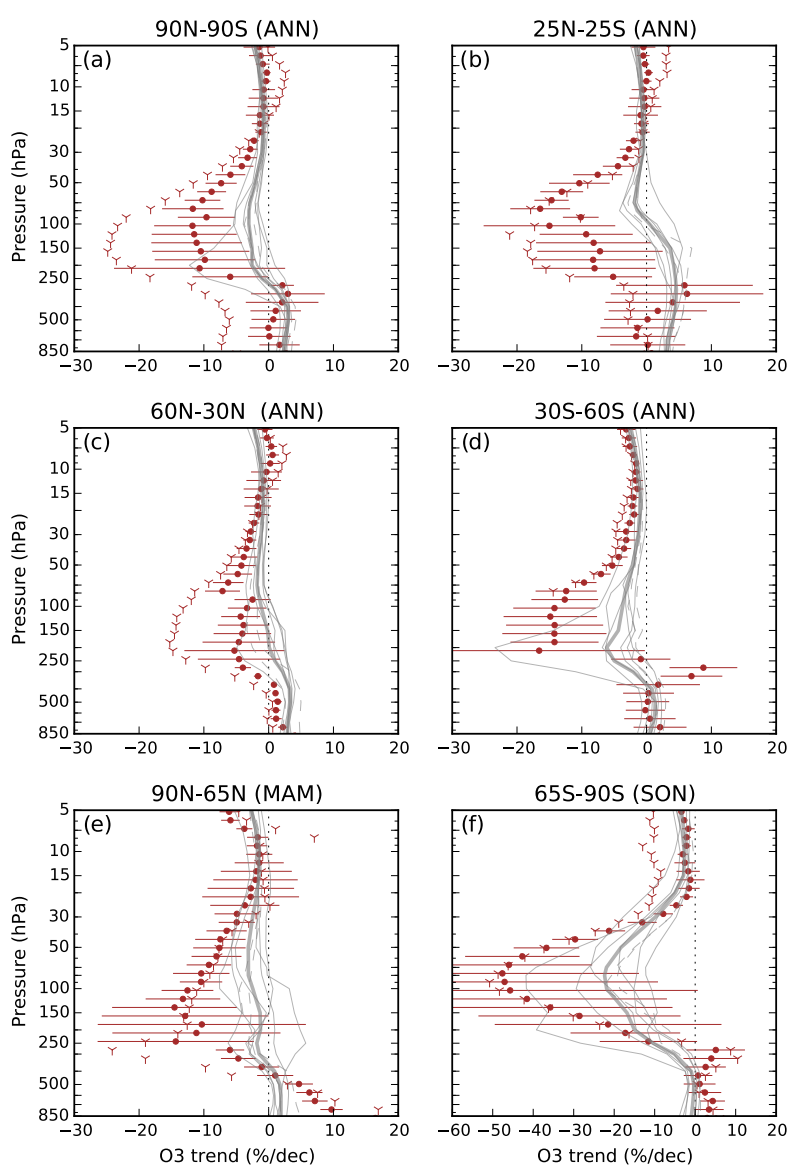

ACCMIP 03 trend $(\% / \mathrm{dec})$

\section{ACCMIP CHEM} ACCMIP NOCHEM

BDBP Tier 0

$\rightarrow$ BDBP Tier 1.4

Figure 2. Vertically resolved ozone trends $\left(\% \mathrm{dec}^{-1}\right)$, for ACCMIP multi-model mean, CHEM and NOCHEM models compared to BDBP Tier 1.4 (regression model fit with uncertainty estimates indicating $95 \%$ confidence intervals, one tail) and Tier 0 (observations).

region. In terms of absolute values, the spread of the ACCMIP models overlaps the observed TCO for the Hist 2000 time slice, though most models differ by more than the observational standard deviation (7 out of 8). Biases in TCO may be attributed to different altitude regions (Fig. 2b). ACCMIP models fail to represent observed ozone depletion occurring in the lower and middle stratosphere region, which may be linked to a poor representation of the $\mathrm{HO}_{x}$ and upwelling in this region (e.g. Lary, 1997; Randel et al., 2007).

In the NH midlatitudes (Fig. 1c), TCO trends in ACCMIP and CMIP5 CHEM models $\left(-0.8\right.$ and $-0.9 \% \mathrm{dec}^{-1}$ respectively) underestimate larger negative trends than observation estimates $\left(-2.3 \pm 1.2 \% \mathrm{dec}^{-1}\right)$, though the CCMVal2 multi-model mean $\left(-1.4 \% \mathrm{dec}^{-1}\right)$ is within the observational uncertainty. TCO decadal trends for IGAC/SPARC and NOCHEM models show better agreement with observations than CHEM models in this region. The ACCMIP Hist

2000 simulation agrees fairly well with observations in terms of absolute values, however, once again most models diverge by more than the observational standard deviation ( 7 out of 8). The ACCMIP multi-model mean falls within the BDBP Tier 1.4 uncertainty estimates for most of the lowermost and middle stratosphere, though simulates weaker ozone depletion in the lower stratosphere, which may be associated with the weaker than observed ozone depletion over the Arctic (Fig. 2c).

Over the Arctic in boreal spring (Fig. 1e), again the ACCMIP CHEM, CMIP5 CHEM and CCMVal2 data sets show weaker decadal trends than observations $\left(-2.1,-2.3\right.$ and $-2.5 \% \mathrm{dec}^{-1}$ respectively compared to $-5.3 \pm 3.3 \% \mathrm{dec}^{-1}$ ). However, TCO for Hist 2000 in ACCMIP is in good agreement with observations, with no individual model differing by more than the observational standard deviation. In the altitude region around $150-30 \mathrm{hPa}$, the ACCMIP multi-model mean is underestimating larger negative trends compared to the BDBP data (Fig. 2e).

In the $\mathrm{SH}$ midlatitudes (Fig. 1d), ACCMIP simulates TCO decadal trends in better agreement with observations than in the $\mathrm{NH}$ midlatitudes $\left(-2.0 \% \mathrm{dec}^{-1}\right.$ compared to $-2.9 \pm 1.3 \% \mathrm{dec}^{-1}$ ), except for the ACCMIP NOCHEM mean which is significantly underestimating larger negative trends $\left(-1.1 \% \mathrm{dec}^{-1}\right)$. In terms of absolute values in present-day conditions, most ACCMIP models' TCO is either high or low biased compared to observations (7 out of $8)$. The ACCMIP multi-model mean is again underestimating larger negative trends compared to the BDBP data set in the altitude range between $150-30 \mathrm{hPa}$ (notice that Tier 1.4 trends are more uncertain in this region), which may be associated to the influence of the tropics and in situ $\mathrm{HO}_{x}$ catalytic loss cycle (e.g. Lary, 1997) (Fig. 2d).

Over Antarctica in austral spring (Fig. 1f), ACCMIP CHEM and CMIP5 multi-model means show best agreement compared to observations $\left(-12.9\right.$ and $-13.9 \% \mathrm{dec}^{-1}$ respectively compared to $\sim-13.9 \pm 10.4 \% \mathrm{dec}^{-1}$ ), although all data sets fall within observational uncertainty estimates. IGAC/SPARC ozone data set and NOCHEM models simulate less ozone depletion in this region $(-11.4$ and $-8.8 \% \mathrm{dec}^{-1}$ respectively) than models with interactive chemistry. Although, many ACCMIP models are in good agreement with observations in terms of absolute values for the Hist 2000 time slice, one CHEM model deviates more than the observational standard deviation. ACCMIP models show fairly good agreement with BDBP Tier 1.4 decadal trends at various altitude regions, except around $70-30 \mathrm{hPa}$, which is also the region where the modelled temperature trends are more negative than observed (see Sect. 5). This is consistent with previous analyses which suggested that models potentially simulate too strong negative trend for a given ozone depletion (e.g. Young et al., 2011) and this discrepancy warrants further investigation in future model intercomparison studies, where there is more model output available. 
Table 2. Global annual mean of TCO (DU).

\begin{tabular}{lcccc}
\hline Scenario & Year & ACCMIP* & CMIP5* & IGAC/SPARC \\
\hline Hist & 1850 & $294 \pm 16$ & $300 \pm 19$ & $293 \pm 1$ \\
& 1980 & $300 \pm 19$ & $306 \pm 20$ & $292 \pm 2$ \\
& 2000 & $291 \pm 16$ & $297 \pm 20$ & $281 \pm 1$ \\
RCP2.6 & 2030 & $295 \pm 16$ & $301 \pm 20$ & $288 \pm 1$ \\
& 2100 & $297 \pm 18$ & $302 \pm 20$ & $294 \pm 0$ \\
RCP8.5 & 2030 & $300 \pm 17$ & $306 \pm 20$ & $290 \pm 1$ \\
& 2100 & $316 \pm 23$ & $323 \pm 11$ & $304 \pm 0$ \\
\hline
\end{tabular}

* For the historical period and the RCPs emission scenarios considered here as calculated from the CHEM models and the IGAC/SPARC data set (see Sect. 2).

The multi-model mean is given along with uncertainties ( \pm 1 standard deviation)

\subsection{Past modelled and future projected total column ozone}

In this section, the evolution of past modelled TCO (from 1850 to 2000) and the sensitivity of ozone to future GHG emissions (from 2030 to 2100) under the lower and higher RCPs scenarios are discussed for the regions and seasons presented in the evaluation section. In the tropical region, TCO evolution is further analysed by looking at the stratospheric (split into upper and lower regions, approximately between 31-48 and 17-25 km respectively) and tropospheric $(<17 \mathrm{~km})$ columns ozone. Historical and future global annual mean of TCO and associated uncertainty $( \pm 1$ standard deviation) for the ACCMIP and CMIP5 CHEM models and the IGAC/SPARC data set is given in Table 2.

To probe how different emissions of GHG affect stratospheric ozone, we only include in this section ACCMIP and CMIP5 models with full ozone chemistry (CHEM). In addition, we compare these results with the IGAC/SPARC database, generally used by those models with prescribed stratospheric ozone. Note that tropospheric column ozone under the RCPs at the end of the 21 st century could lead to differences in TCO around $20 \mathrm{DU}$, due to differences in ozone precursors emissions (e.g. methane) (Young et al., 2013a). Again, vertical resolved ozone changes are presented to give insight on the vertical distribution of ozone changes (for the 1850-2100 and 2000-2100 periods).

Figure 3 shows, except for the extratropical regions in the $\mathrm{SH}$, an increase in TCO from the pre-industrial period (Hist 1850) to the near-past (Hist 1980) owing to ozone precursors emissions. In the SH extratropical, due to special conditions (e.g. greater isolation from the main sources of ozone precursors and stratospheric cold temperatures during austral winter and early spring), there is a decrease in TCO that is particularly pronounced over Antarctica $(-12.4 \%)$. Between near-past and present-day (Hist 2000), a period characterized by ODS emissions, the TCO decreases everywhere, with the magnitude being dependent on the region. Thus, the relative change of TCO between the present-day and pre-industrial periods varies across different regions, mainly
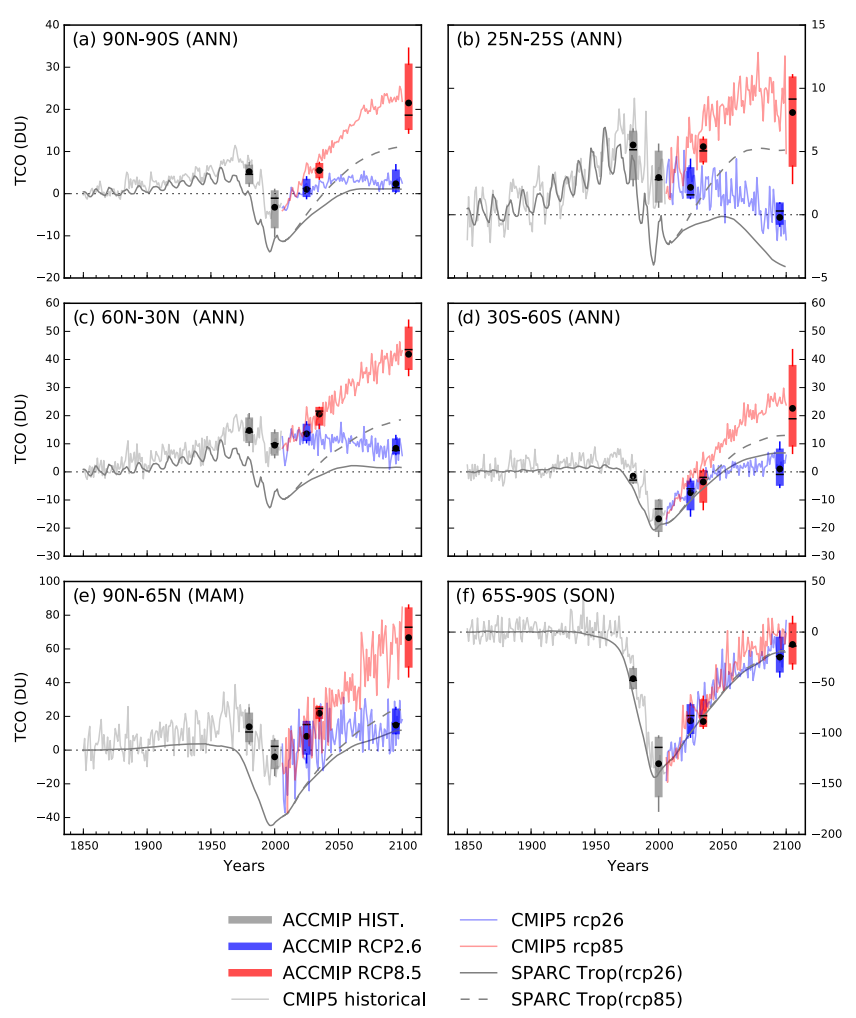

Figure 3. Total column ozone (DU) time series from 1850 to 2100 , normalized to Hist 1850 time slice levels. The box, whiskers, and line indicate the interquartile range, $95 \%$ range and median respectively, for the ACCMIP CHEM models. In addition, the multi-model mean of the CMIP5 CHEM models and the IGAC/SPARC mean are shown.

due to the competing effects of ozone precursors and ODS emissions (approximately, from $2.9 \%$ in the $\mathrm{NH}$ midlatitudes and $-34.9 \%$ over Antarctica). Notice, however, that minimal stratospheric ozone depletion occurs before the 1960s.

Future TCO projected for the RCPs 2100 time slices relative to present-day are affected by the impact of the Montreal Protocol on limiting ODS emissions, climate change, and ozone precursors emissions. TCO changes between 2000 and 2100 relative to the pre-industrial period for the low and high emission scenarios are in the range of approximately from -1.2 to $2.0 \%$ in the tropics and $28.3-31.7 \%$ over Antarctica, respectively. Ozone "super-recovery", defined here as higher stratospheric ozone levels than those during pre-ozone depletion (1850), is found for ACCMIP CHEM models in RCP8.5 2100 in all regions and seasons, with the exception in the tropics and over Antarctica during austral spring. As expected from the above climate impacts, the biggest superrecovery is found, in the order of $12.6 \%$ over the Arctic during boreal spring, and between 3.9-6.5\% at midlatitudes for the RCP8.5 2100 time slice. Similar levels of stratospheric ozone super-recovery are found in the CMIP5 CHEM models. In contrast, the IGAC/SPARC database only projects 

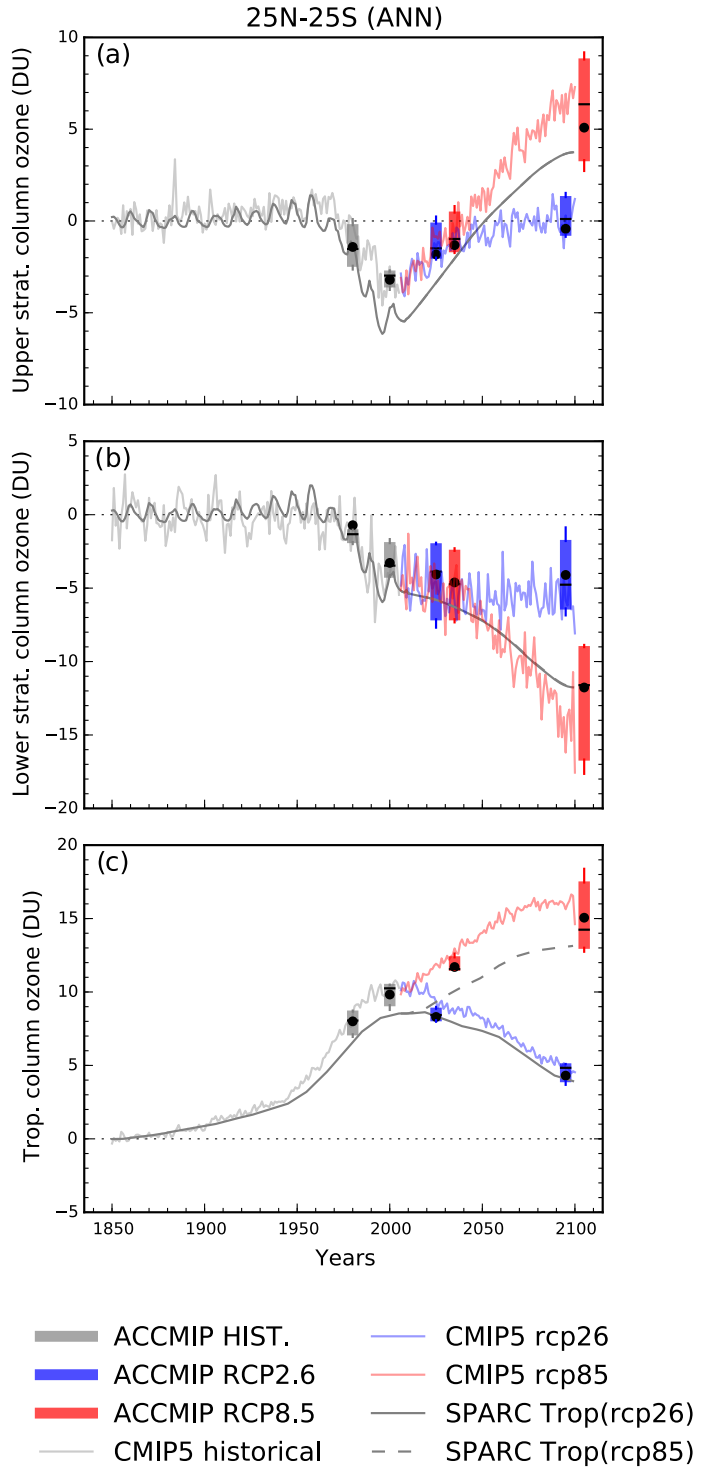

Figure 4. As Fig. 3, but for the upper stratosphere (10-1 hPa), lower stratosphere $(>15 \mathrm{hPa})$, and tropospheric columns ozone (DU) in the tropics.

small super-recovery in the $\mathrm{NH}$ polar region and at midlatitudes in the SH. These ozone super-recovery results are consistent with recent findings on stratospheric ozone sensitivity to GHG concentrations (Waugh et al., 2009a; Eyring et al., 2010b).

We give special attention to TCO projections in the tropics, since an acceleration of the BDC, due to increases in GHG concentrations would lead to a rise of tropospheric ozonepoor air entering the tropical lower stratosphere (Butchart et al., 2006, 2010, 2011; SPARC-CCMVal, 2010; Eyring et al., 2013). In other words, ozone concentrations in the lower stratosphere would decrease with high GHG emissions.
Figure 4 presents upper $(10-1 \mathrm{hPa})$ and lower $(>15 \mathrm{hPa})$ stratospheric and tropospheric columns ozone in the tropics, from the pre-industrial period to the end of the 21 st century. Tropospheric column ozone increases with higher ozone precursors emissions during the historical period (1850-2000). Future emissions of ozone precursors (e.g. $\mathrm{CO}$ and $\mathrm{NO}_{x}$ ) are fairly similar among the RCPs scenarios, decreasing to various degrees between the present-day and 2100 (van Vuuren et al., 2011). The exception is that the methane burden under the RCP8.5 scenario roughly doubles by the end of the 21st century (Meinshausen et al., 2011). Mainly due to the methane burden and the stratospheric ozone influence via STE, ACCMIP CHEM tropospheric column ozone change by 2100 relative to present-day is -5.5 and $5.2 \mathrm{DU}$, for the RCP2.6 and RCP8.5 scenarios respectively. For both stratospheric columns ozone, there is a small decrease from the pre-industrial period to present-day (-3.2-3.3 DU), which remained fairly constant by 2030 for both RCPs scenarios. Although ODS concentrations decrease during the 21st century, two different stories occur in the second half of the century. In the upper stratosphere, ozone amounts return to preindustrial levels under the low emission scenario by 2100 . However, RCP8.5 2100 ozone levels relative to present-day increase $8.3 \mathrm{DU}$, due to a slow down of the ozone catalytic loss cycles, linked to the stratospheric cooling (e.g. Haigh and Pyle, 1982; Portmann and Solomon, 2007; Revell et al., 2012; Reader et al., 2013). In the lower stratosphere, ozone levels change little ( $-0.8 \mathrm{DU}$ ) by 2100 relative to the presentday for the RCP2.6, though decrease by $-8.5 \mathrm{DU}$ under the RCP8.5 scenario, likely due to the acceleration of the BDC. In summary, stratospheric column ozone by 2100 remains fairly similar to the present-day, although different stories are drawn in the upper and lower stratosphere. Future TCO changes in the tropics are mainly determined by the upper stratospheric ozone sensitivity to GHG concentrations, due to a large compensation between tropospheric and lower stratospheric column ozone changes in the RCP2.6 and RCP8.5 emission scenarios. Notice that tropospheric column ozone in the RCP8.5 2100 time slice is largely the result of future increase in methane.

Figure 5 presents vertically resolved ozone change between the Hist 1850 and RCPs 2100 time slices and between the Hist 2000 and RCPs 2100 time slices (top and bottom rows, respectively). In contrast to the tropics, the midlatitudes lower stratospheric ozone is positively correlated to GHG concentrations (Fig. 5b and d) mainly due to the influx of relatively "rich" ozone air from lower latitudes (e.g. WMO, 2011) from a strengthened BDC. Additionally, the increase in methane emissions in the RCP8.5 scenario results in chemically driven increases in ozone in this region (e.g. Randeniya et al., 2002; Reader et al., 2013). However, middle and upper stratospheric ozone sensitivity to GHG concentrations behaves the same as in the tropics. Substantial ozone increases are simulated by 2100 , in the altitude region of the upper troposphere-lower stratosphere and the middle and up- 

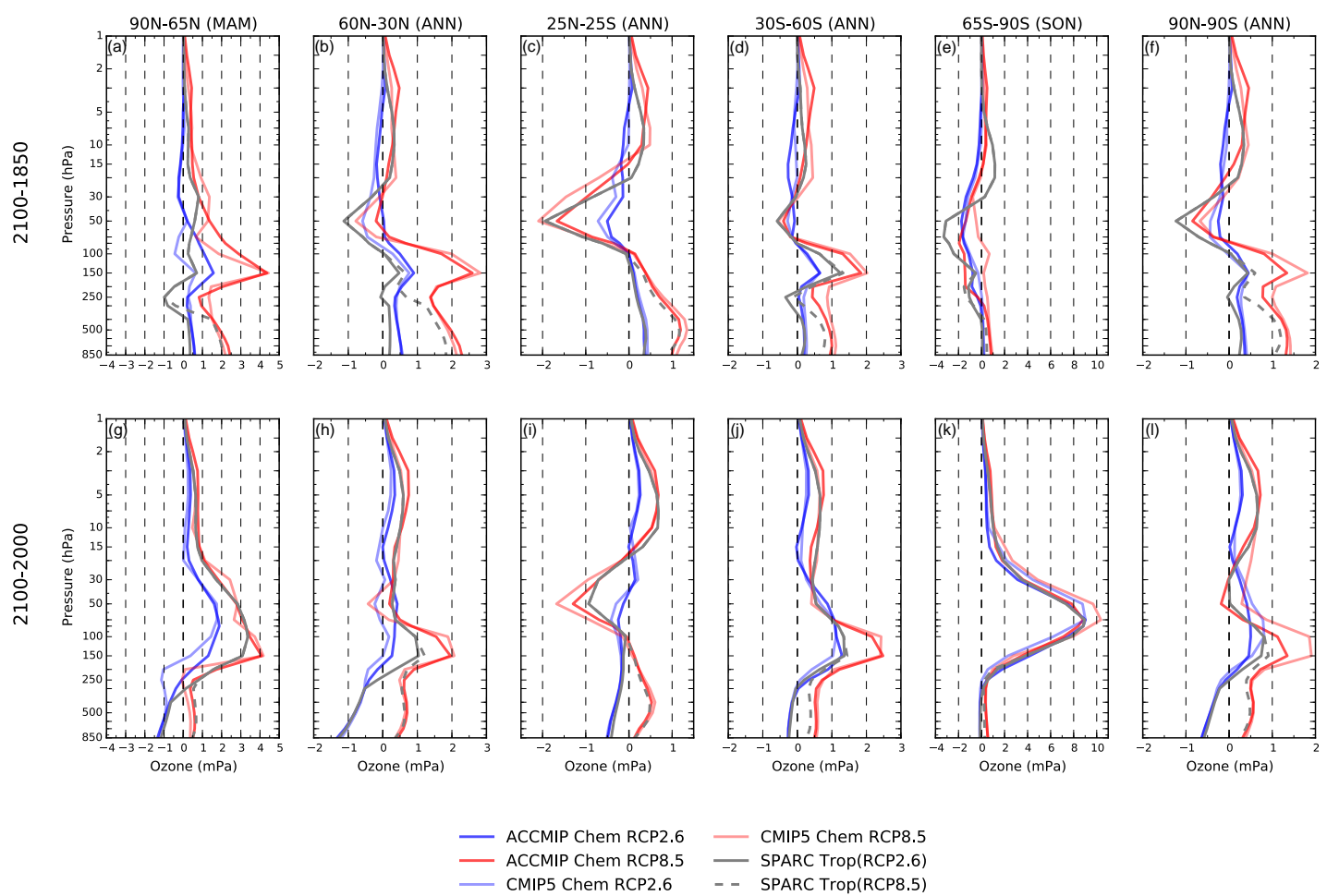

Figure 5. Vertically resolved ozone change between 2100 and 1850 (a to f), and 2100 and 2000 (g to l) time slices. Figures (a)-(g) are for Arctic boreal spring mean, (b)-(h) and (d)-(j) for NH and SH midlatitudes annual mean respectively, (c)-(i) for tropical annual mean, (e)-(k) for Antarctic austral spring mean, and (f)-(l) for global annual mean.

per stratosphere, relative to pre-industrial (1850) and presentday (2000) levels. We note that climate impact in ozone levels is weaker in the southern than in the northern midlatitudes for the ACCMIP and CMIP5 multi-model means, likely due to hemispheric differences in STE and ozone flux (Shepherd, 2008), which is in contrast to IGAC/SPARC data set. TCO for the RCP8.5 2100 time slice is $6.9-13.1 \%$ higher than those simulated in the Hist 1850 time slice. While, the RCP2.6 2100 time slice in the northern midlatitudes is similar to present-day levels, in the southern midlatitudes is similar to pre-industrial levels. This is mainly due to regional differences in ozone precursors emissions and the tropospheric ozone contribution (Fig. 3c-d).

Over the Arctic in boreal spring (Fig. 3e), results similar to those in the northern midlatitudes are found for all models, though higher stratospheric ozone sensitivity to GHG concentrations lead to approximately two times larger scenario differences for the 2100 time slice (37.7 DU between RCP2.6 and RCP8.5). In addition to the RCP8.5 emission scenario, ozone super recovery is also simulated under the RCP2.6 scenario by ACCMIP and CMIP5 CHEM models. The IGAC/SPARC data set projects similar results to those under the latter scenario. Note that the ACCMIP and CMIP5 multi-model means show a small increase in TCO by 1980 and no significant ozone depletion by 2000 relative to 1850 . This is in sharp contrast to the polar region in the SH, which highlights both regional differences in ozone precursors sources and atmospheric conditions.

Over Antarctica during austral spring (Fig. 3f), TCO evolution is more isolated from GHG effects and ozone precursors than in other regions. In agreement with previous studies, ACCMIP and CMIP5 CHEM models project similar values under the lower and higher GHG scenarios (Austin et al., 2010; SPARC-CCMVal, 2010; Eyring et al., 2013). TCO in the RCPs 2100 time slices remained below 1850s levels $(-3.3-6.7 \%)$. This suggests decreasing ODS concentrations during the 21 st century as the main driver of stratospheric ozone in this region and season (i.e. ozone super-recovery is found for RCP8.5 2100 in other seasons). Furthermore, vertical distribution changes of stratospheric ozone in 2100, compared to 1850 (Fig. 5f1), and 2000 (Fig. 5f2), show small differences between the above scenarios (e.g. small sensitivity to GHG concentrations). Evolution of stratospheric ozone at high latitudes in the $\mathrm{SH}$, particularly during spring season, has implications over surface climate due to modifications in temperature and circulation patterns as shown by previous studies. 

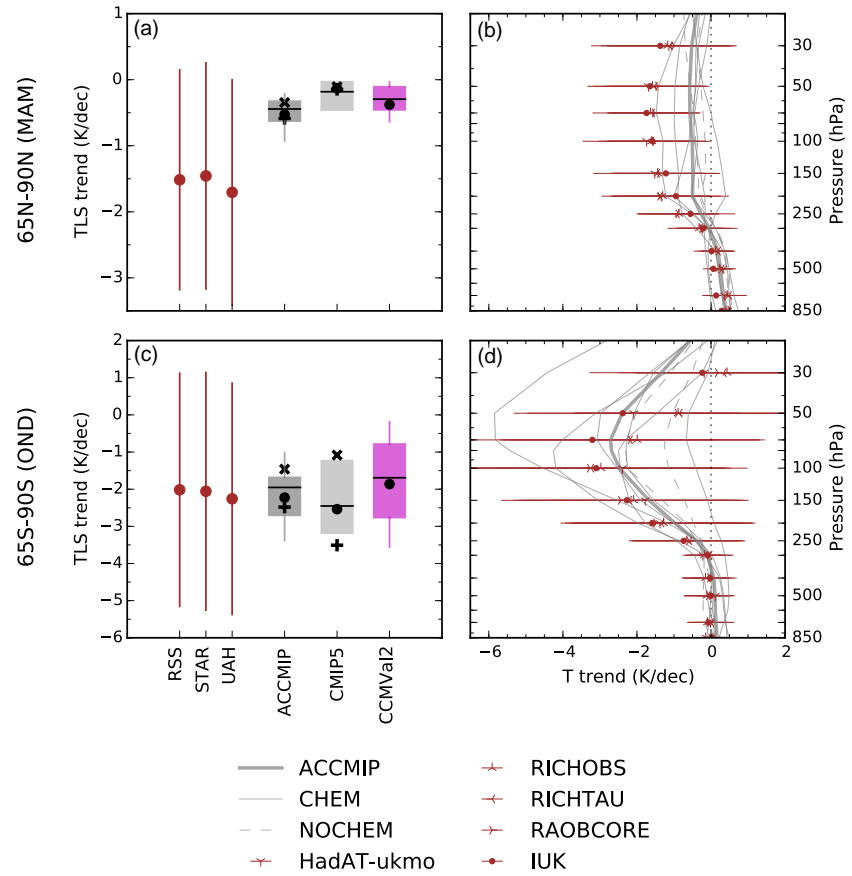

Figure 6. Temperature trends from 1980 to $2000\left(\mathrm{~K} \mathrm{dec}^{-1}\right)$. Figures (a) and (c) represent MSU temperature lower stratosphere (TLS) for MAM in the Arctic and for OND in the Antarctic. The box, whiskers, line, dot, "plus", and "cross" symbols show the interquartile range, $95 \%$ range, median, multi-model mean, CHEM, and NOCHEM means respectively, for the ACCMIP (light grey), CMIP5 (dark grey) and CCMVal2 (magenta) models. Figures (b) and (d) represent vertically resolved temperature $(T)$ trends for the ACCMIP simulations (light grey). Observational data sets are represented by error bars indicating the $95 \%$ confidence intervals (one tail).

\section{Stratospheric ozone changes and associated climate impacts in the Southern Hemisphere}

To probe stratospheric ozone evolution and climate interactions (1850-2100), we first examine simulated stratospheric temperatures in Sect. 4.1. SAM index evolution is presented in Sect. 4.2. Note that ozone loss over the Arctic in boreal spring is only around $25 \%$ of the depletion observed in the Antarctic (see also Fig. 1e), and is not believed to have a significant role in driving NH surface climate (e.g. Grise et al., 2009; Eyring et al., 2010a; Morgenstern et al., 2010a).

\subsection{Lower stratospheric temperatures changes}

Figure 6 shows recent stratospheric temperature decadal trends (1980-2000) in polar regions during springtime (March-April-May in the Arctic and October-NovemberDecember in the Antarctic). The figure compares temperature in the lower stratosphere (TLS) in the ACCMIP, CMIP5 and CCMVal2 models with observational estimates based on Microwave Sounding Unit (MSU) retrievals by the Remote
Sensing Systems (RSS - version 3.3) (Mears et al., 2011), the Satellite Applications and Research (STAR - version 3.0) (Zou et al., 2006, 2009), and the University of Alabama in Huntsville (UAH - version 5.4) (Christy et al., 2003) (Fig. 6a-c). The TLS vertical weighting function from RSS is used to derive MSU temperature from climate models output. Temperature vertical profile decadal trends in the ACCMIP models (Fig. 6b-d) are compared against radiosonde products of the Radiosonde Observation Correction Using Reanalyses (RAOBCORE - version 1.5), Radiosonde Innovation Composite Homogenization (RICH-obs and RICH-tau version 1.5) (Haimberger et al., 2008, 2012), the Hadley Centre radiosonde temperature product (HadAT2) (Thorne et al., 2005), and the Iterative Universal Kriging (IUK) Radiosonde Analysis Project (Sherwood et al., 2008) (version 2.01).

Over the $\mathrm{NH}$ polar cap in boreal spring, although ACCMIP, CMIP5, and CCMVal2 models are within observational estimates, all simulate weaker decadal trends $\left(-0.5,-0.1\right.$ and $-0.4 \mathrm{~K} \mathrm{dec}^{-1}$, respectively) than observed $\left(-1.6 \pm 3.4 \mathrm{~K} \mathrm{dec}^{-1}\right)$ (Fig. 6a). Natural variability in models not constrained by observed meteorology is difficult to reproduce (Austin et al., 2003; Charlton-Perez et al., 2010, 2013; Butchart et al., 2011; Shepherd et al., 2014) such as, the abnormally cold boreal winters in the mid-1990s (i.e. more PSCs formation), which resulted in enhanced ozone loss during boreal spring (Newman et al., 2001). Moreover, ACCMIP simulations, based on time slice experiments for most models, did not embrace that period, only those boundary conditions for 1980 and 2000 years. This weaker trend on stratospheric temperature is also seen in the vertical profile above around the tropopause (Fig. 6b).

Over Antarctica in austral spring, the ACCMIP and CMIP5 multi-model means are in very good agreement $\left(-2.2,-2.5 \mathrm{~K} \mathrm{dec}^{-1}\right.$ respectively) with satellite measurements $\left(-2.1 \pm 6.3 \mathrm{~K} \mathrm{dec}^{-1}\right.$ ) (Fig. 6c). CHEM models (i.e. ACCMIP and CMIP5) and CCMVal2 multi-model mean tend to simulate larger negative trends than NOCHEM models, which may be due to the fact that the IGAC/SPARC ozone data set is at the lower end of the observational estimates as has been shown in Solomon et al. (2012), Hassler et al. (2013), Young et al. (2014). They argued the importance of the ozone data set for appropriate representation of stratospheric temperature, and in turn SH surface climate. Although, large uncertainties exist in this region and period, all ACCMIP individual models fall within the observational error estimates (Fig. 6d). Note that observational estimates are significant at the $95 \%$ confidence levels, if year 2000 is removed from the linear fit $(-2.95 \pm 2.90,-3.02 \pm 2.95$ and $-3.12 \pm 2.87 \mathrm{~K} \mathrm{dec}^{-1}$ for the RSS, STAR and UAH data sets, respectively), as this year was "anomalously" warm. The relatively large spread of the simulated stratospheric temperature trend for the observational period is consistent with the models spread of ozone in this region (Figs. If and 2f). The correlation between stratospheric ozone and temperature trends becomes evident by comparing TCO trends 

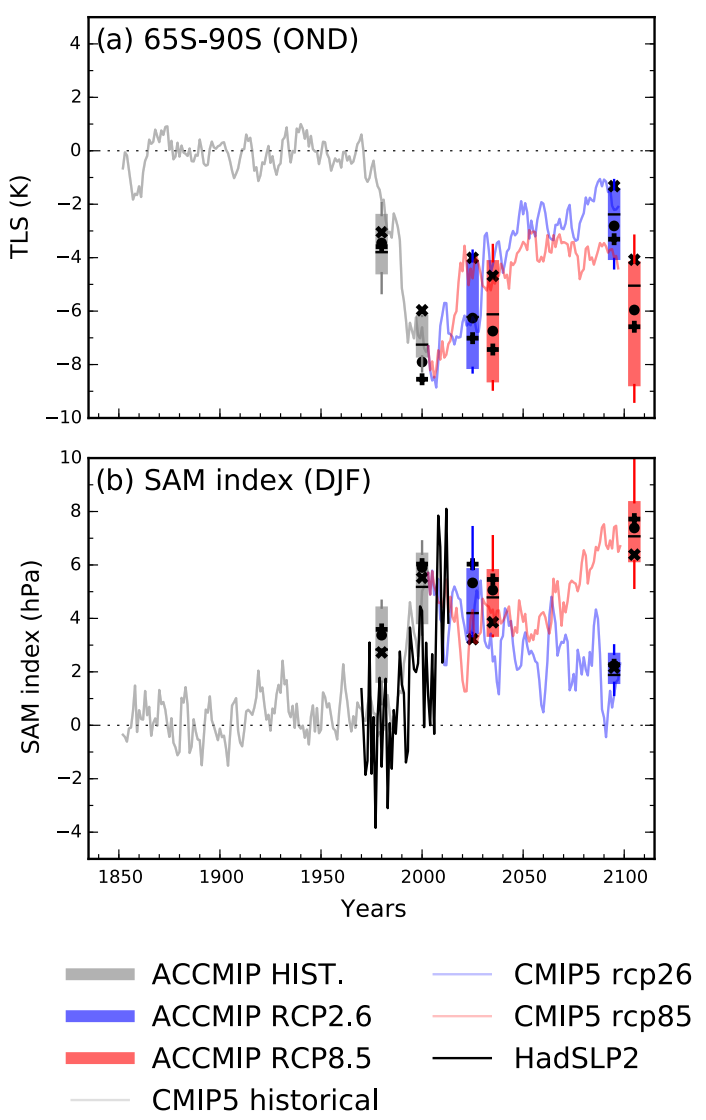

Figure 7. (a) MSU temperature lower stratosphere (TLS) and (b) SAM index time series from 1850 to 2100 . The box, whiskers, line, dot, "plus", and "cross" symbols show the interquartile range, $95 \%$ range, median, multi-model mean, CHEM, and NOCHEM means respectively, for the ACCMIP models. The 5-years average of the CMIP5 multi-model mean is shown. In addition, HadSLP2 observational data set for (b) is represented by a solid black line. The ACCMIP models are normalized to Hist 1850 time slice levels, and the HadSLP2 data set and CMIP5 models are relative to 1860-1899 climatology.

between the Hist 1980 and 2000 time slices and TLS trends for the same period between CHEM and NOCHEM models (i.e. large ozone depletion results in stronger stratospheric cooling trends).

Figure 7a depicts SH polar cap TLS long-term evolution (1850-2100) normalized to pre-industrial levels during austral spring. As commented above, stratospheric temperature can be perturbed by anthropogenic emissions of ODS and GHG, both having a net cooling effect. ACCMIP Hist 1980 and 2000 TLS time slices $(-3.4$ and $-7.9 \mathrm{~K})$ are driven by the combination of ozone depletion and climate change since the pre-industrial period. In future projections, ozone recovery and GHG concentrations are expected to have an opposite effect on stratospheric temperatures. The slight temperature increase of the TLS by 2030 in the RCPs time slices relative to present-day, is very similar between the lower and higher
RCPs emission scenarios (1.6 and $1.2 \mathrm{~K}$, respectively). By the end of the 21 st century, the projected TLS under the RCP2.6 scenario returns to Hist 1980 levels, whereas it remains fairly unchanged under the RCP8.5 scenario relative to 2030. These two different stories suggest a key role of GHG concentration in the second half of the century, with significant implications for many aspects of the SH surface climate as reported previously (McLandress et al., 2011; Perlwitz, 2011; Polvani et al., 2011); see Sect. 4.2, Thompson et al. (2011) and Previdi and Polvani (2014) for a comprehensive review.

\subsection{Southern annular mode evolution}

The SAM index is defined as per Gong and Wang (1999), by subtracting the zonal mean sea level pressure (SLP) at $65^{\circ} \mathrm{S}$ latitude from the zonal mean SLP at $40^{\circ} \mathrm{S}$ latitude from monthly mean output. The SAM index is a proxy of variability in the jets captured by SLP anomalies at middle and high latitudes (e.g. Thompson and Wallace, 2000).

Figure $7 \mathrm{~b}$ shows SAM index long-term evolution (18502100) normalized to 1850 levels during austral summer. Observational estimates based on the Hadley Centre Sea Level Pressure data set (HadSLP2) are shown from 1970 to 2012. The ACCMIP multi-model mean shows a positive trend between Hist 1980 and 2000 time slices $\left(1.3 \mathrm{hPa} \mathrm{dec}^{-1}\right)$, coinciding with the highest ozone depletion period. Within uncertainty, this is weaker than observational estimates $\left(2.2 \pm 1.1 \mathrm{hPa} \mathrm{dec}^{-1}\right)$. ACCMIP CHEM and NOCHEM models show similar SAM index trends, although the latter presents weaker TLS trends (see Fig. 6c). As seen in Fig. 7a for the TLS in austral spring, by 2030 for both RCPs scenarios the ACCMIP multi-model mean shows a slight decrease in the SAM index relative to Hist 2000.

Two different stories are drawn from 2030 to 2100 . The SAM index simulated under the RCP2.6 scenario tends to return to "normal" levels $\left(-0.4 \mathrm{hPa} \mathrm{dec}^{-1}\right)$, as ODS concentrations and GHG emissions decrease during the second half of the century. In contrast, under the RCP8.5 scenario GHG concentrations increase, resulting in a positive trend of the SAM index $\left(0.3 \mathrm{hPa} \mathrm{dec}^{-1}\right)$. By using two independent samples Student's $t$ test, we find that SAM index changes between Hist 2000 and 2100 relative to Hist 1850, are significant for the RCP2.6 at the $5 \%$ level, although is not significant for the RCP8.5. CMIP5 multi-model mean shows better agreement with observations during the record period $\left(2.1 \mathrm{hPa} \mathrm{dec}^{-1}\right)$ than ACCMIP. During the second half of the 21st century (2030-2100), however, the CMIP5 multi-model mean shows consistent projections with the latter $(-0.4$ and $0.4 \mathrm{hPa} \mathrm{dec}^{-1}$ for RCP2.6 and RCP8.5, respectively). 


\section{Discussion}

TCO trends in ACCMIP models compare favourably with observations, however, smaller ozone negative trends in the tropical lower stratosphere are simulated. It has been argued that tropical upwelling (or the BDC) is the main driver in this region determining ozone levels (Lamarque and Solomon, 2010; Polvani and Solomon, 2012), with chemical processes playing a minor role (e.g. Meul et al., 2014). However, observed BDC and its seasonal cycle (Fu et al., 2010; Young et al., 2011) are poorly constrained in modelling studies (e.g. Butchart et al., 2006; Garcia and Randel, 2008; Butchart et al., 2010). This is important since ozone depletion determines to a large extent the temperatures in the lower stratosphere (e.g. Polvani and Solomon, 2012) (note that ACCMIP models show smaller negative temperature trends in this region compared to observations, not shown), and the latter triggers significant feedbacks in climate response (Stevenson, 2015). Models with less ozone depletion in the tropical lower stratosphere may have stronger climate sensitivity (Dietmüller et al., 2014; Nowack et al., 2015).

Long-term TCO changes relative to Hist 1850 in the ACCMIP models considered in this study, are least consistent for Hist 2000 in the Antarctic springtime (i.e. the period with large ozone losses) and for RCP8.5 2100 in general. The latter may be linked to uncertainties due to sensitivity of ozone to future GHG emissions (i.e. various direct and indirect processes affecting ozone amounts in the troposphere and the stratosphere). For example, $\mathrm{CO}_{2}$ and methane mixing ratios increase by more than 3 and 4 times in RCP8.5 2100 relative to the pre-industrial period, respectively. Nevertheless, the ACCMIP and CMIP5 multi-model means show consistent RCP8.5 2100 projections. Although TCO changes are relative to the Hist 1850, a period without direct measurements (e.g. estimates with large uncertainties), ACCMIP models show good agreement compared to other time slices. For example, the interquartile range (central $50 \%$ of the data) varies approximately $3-8 \%$ of the corresponding mean value across the regions and seasons considered here.

Stratospheric ozone has been shown to be asymmetrical over the SH polar cap (Grytsai et al., 2007). Prescribing zonal mean ozone fields in CCMs may have implications on SH climate (e.g. Crook et al., 2008; Gillett et al., 2009), particularly in early spring stratospheric temperatures (September-October) and, though less pronounced, in November-December (Calvo et al., 2012; Young et al., 2013b). During strong depletion periods such as in the recent past (1980-2000) and in the near-future (2000-2030), eliminating zonal asymmetry may result in a poor representation of stratospheric and tropospheric climate trends in the SH (Waugh et al., 2009b). Moreover, prescribing stratospheric ozone may lead to inconsistencies and skew the climate response (e.g. Nowack et al., 2015). We showed that NOCHEM models simulated both weaker springtime TLS negative trends over the Antarctic compared to observational estimates, and stronger positive trends in the near-future compared to CHEM models. In addition, Young et al. (2014) found 20-100\% larger tropospheric climate responses in this region and season with a climate model driven by the BDBP data set compared to the SPARC/IGAC data set used in NOCHEM models here. ACCMIP CHEM and NOCHEM models show most disagreement on SAM index trends in the near-future, period with relatively strong ozone depletion (> Hist 1980). The former projects negligible trends compared to $-0.57 \mathrm{hPa} \mathrm{dec}^{-1}$ and three times weaker negative trends than the latter, for the RCP2.6 and RCP8.5 respectively. This is consistent with CHEM and NOCHEM TLS springtime trends in this period and region. Nevertheless, ACCMIP models participating in this study agree with previous observational (e.g. Thompson and Solomon, 2002; Marshall, 2003, 2007) and modelling studies (e.g. Gillett and Thompson, 2003; Son et al., 2008, 2009, 2010; Polvani et al., 2010; Arblaster et al., 2011; McLandress et al., 2011; Polvani et al., 2011; Gillett and Fyfe, 2013; Keeble et al., 2014) on the SH surface climate response, measured here using the SAM index.

\section{Summary and conclusions}

This study has analysed stratospheric ozone evolution from 1850 to 2100 from a group of chemistry climate models with either prescribed or interactively resolved time-varying ozone in the stratosphere and participated in the ACCMIP activity ( 8 out of 16 models). We have evaluated TCO and vertically resolved ozone trends between 1980 and 2000, and examined past and future ozone projections under the low and high RCPs future emission scenarios (RCP2.6 and RCP8.5, respectively). Finally, we have assessed TLS and temperature profile trends at high latitudes in the recent past, and analysed TLS and SH surface climate response (diagnosed using the SAM index), from the pre-industrial period to the end of the 21st century.

Within uncertainty estimates, the ACCMIP multi-model mean TCO compares favourably with recent observational trends (1980-2000), although individual models often show significant deviations, particularly those models that include interactive chemistry. The closest agreement of TCO to observations is found over the Antarctic in austral spring (the ozone hole). The largest disagreement with observations is found for NH high latitudes during boreal spring, although this may be due to a series of cold winters and associated additional PSCs formation during the mid- 1990s (Newman et al., 2001) - driving stronger ozone depletion - which are not captured by the use of time slice integrations (Hist 1980 and 2000). In addition, over the tropics the ACCMIP models fail to simulate ozone reductions in the lower stratosphere over the same period, which could be linked to trends in tropical upwelling (e.g. Polvani and Solomon, 2012). 
The results corroborate previous findings (Waugh et al., 2009a; Eyring et al., 2010b, 2013), suggesting that changes in stratospheric ozone due to future increases in $\mathrm{GHG}$ concentrations are most sensitive over the Arctic and the $\mathrm{NH}$ midlatitudes (37.7 and 16.1 DU difference between the RCP2.6 and RCP8.5 by 2100, respectively), with the smallest sensitivity in the tropics and over Antarctica (2.5 and 8.1 DU respectively). In the tropics, upper stratospheric ozone sensitivity to GHG concentrations will largely determine TCO future evolution, due to a trade-off between lower stratospheric and tropospheric columns ozone during the 21 st century under the RCP2.6 and RCP8.5 emission scenarios.

The ACCMIP simulations of the trends in TLS and temperature profile over 1980-2000 agree well with satellite and radiosonde observations over the Antarctic in austral spring. ACCMIP CHEM models agree better with observations than the CMIP5 CHEM ensemble used here for the same period and region. However, ACCMIP models using prescribed time-varying stratospheric ozone (NOCHEM) show weaker trends than observational estimates in the recent past (19802000), and stronger positive trends than models with stratospheric chemistry online (CHEM) in the near-future (20002030). This highlights the importance of the ozone database used to drive models on the climate response. For example, Young et al. (2014) found large differences in SH surface climate responses when using different ozone data sets.

Overall, stratospheric ozone and associated climate impacts are fairly well represented by the ACCMIP ensemble mean in the recent past (1980-2000), and individual models also agree on the sign and distribution of past and future changes (1850-2100). In line with previous multi-model analyses (Son et al., 2008, 2010; Eyring et al., 2010a, 2013; Gillett and Fyfe, 2013), and observation studies (Thompson and Solomon, 2002; Marshall, 2003, 2007), the ACCMIP models show strong positive trends of the SAM index in austral summer during the ozone depletion period (1.3 hPa dec $\left.{ }^{-1} 1980-2000\right)$, which is in agreement with observations $\left(2.2 \pm 1.1 \mathrm{hPa} \mathrm{dec}^{-1}\right)$. While in the recent past both ozone depletion and increasing GHGs have favoured a strengthening of the SAM during summer, under projected ozone recovery they will drive the SAM into opposite directions. Under the low emission scenario, the SAM index tends to return to pre-industrial levels from around the second half of the 21 st century $\left(-0.4 \mathrm{hPa} \mathrm{dec}^{-1}\right.$ between $\left.2030-2100\right)$; i.e. the impact of ozone recovery is stronger than GHG. In contrast, with the higher emission scenario, the GHGdriven SAM trend exceeds the opposing ozone recoverydriven trend, and the SAM index continues on its positive trend ( $0.3 \mathrm{hPa} \mathrm{dec}^{-1}$ between $\left.2030-2100\right)$.

In this study we have presented stratospheric ozone evolution (1850-2100) using a number of models that participated in the ACCMIP activity. We have demonstrated both its key role in the present and future $\mathrm{SH}$ climate and the importance of how it is represented in climate models. These results and work over the last decade have shown that changes in stratospheric ozone are tightly coupled to the climate (e.g. SPARC-CCMVal, 2010; Nowack et al., 2015), supporting the idea of including these processes interactively in models. It is clear that our ability to understand future climate will depend on models that can reliably simulate these chemistry-climate feedbacks.

Acknowledgements. This work was supported by NERC, under project number NE/L501736/1. F. Iglesias-Suarez would like to acknowledge NERC for a PhD studentship. We thank the modelling groups that contributed to the ACCMIP, CMIP5 and CCMVal2 model intercomparison projects and provided the model results used in this study.

Edited by: J. Kuttippurath

\section{References}

Arblaster, J. M. and Meehl, G. A.: Contributions of External Forcings to Southern Annular Mode Trends, J. Climate, 19, 28962905, doi:10.1175/JCLI3774.1, 2006.

Arblaster, J. M., Meehl, G. A., and Karoly, D. J.: Future climate change in the Southern Hemisphere: Competing effects of ozone and greenhouse gases, Geophys. Res. Lett., 38, L02701, doi:10.1029/2010GL045384, 2011.

Austin, J. and Wilson, R. J.: Ensemble simulations of the decline and recovery of stratospheric ozone, J. Geophys. Res., 111, D16314, doi:10.1029/2005JD006907, 2006.

Austin, J., Shindell, D., Beagley, S. R., Brühl, C., Dameris, M., Manzini, E., Nagashima, T., Newman, P., Pawson, S., Pitari, G., Rozanov, E., Schnadt, C., and Shepherd, T. G.: Uncertainties and assessments of chemistry-climate models of the stratosphere, Atmos. Chem. Phys., 3, 1-27, doi:10.5194/acp-3-1-2003, 2003.

Austin, J., Scinocca, J., Plummer, D., Oman, L., Waugh, D., Akiyoshi, H., Bekki, S., Braesicke, P., Butchart, N., Chipperfield, M., Cugnet, D., Dameris, M., Dhomse, S., Eyring, V., Frith, S., Garcia, R. R., Garny, H., Gettelman, A., Hardiman, S. C., Kinnison, D., Lamarque, J. F., Mancini, E., Marchand, M., Michou, M., Morgenstern, O., Nakamura, T., Pawson, S., Pitari, G., Pyle, J., Rozanov, E., Shepherd, T. G., Shibata, K., Teyssèdre, H., Wilson, R. J., and Yamashita, Y.: Decline and recovery of total column ozone using a multimodel time series analysis, J. Geophys. Res., 115, D00M10, doi:10.1029/2010JD013857, 2010.

Barnes, E. A., Barnes, N. W., and Polvani, L. M.: Delayed Southern Hemisphere Climate Change Induced by Stratospheric Ozone Recovery, as Projected by the CMIP5 Models, J. Climate, 27, 852-867, doi:10.1175/JCLI-D-13-00246.1, 2013.

Bodeker, G. E., Shiona, H., and Eskes, H.: Indicators of Antarctic ozone depletion, Atmos. Chem. Phys., 5, 2603-2615, doi:10.5194/acp-5-2603-2005, 2005.

Bodeker, G. E., Hassler, B., Young, P. J., and Portmann, R. W.: A vertically resolved, global, gap-free ozone database for assessing or constraining global climate model simulations, Earth Syst. Sci. Data, 5, 31-43, doi:10.5194/essd-5-31-2013, 2013.

Bönisch, H., Engel, A., Birner, Th., Hoor, P., Tarasick, D. W., and Ray, E. A.: On the structural changes in the Brewer-Dobson 
circulation after 2000, Atmos. Chem. Phys., 11, 3937-3948, doi:10.5194/acp-11-3937-2011, 2011.

Bowman, K. W., Shindell, D. T., Worden, H. M., Lamarque, J. F., Young, P. J., Stevenson, D. S., Qu, Z., de la Torre, M., Bergmann, D., Cameron-Smith, P. J., Collins, W. J., Doherty, R., Dalsøren, S. B., Faluvegi, G., Folberth, G., Horowitz, L. W., Josse, B. M., Lee, Y. H., MacKenzie, I. A., Myhre, G., Nagashima, T., Naik, V., Plummer, D. A., Rumbold, S. T., Skeie, R. B., Strode, S. A., Sudo, K., Szopa, S., Voulgarakis, A., Zeng, G., Kulawik, S. S., Aghedo, A. M., and Worden, J. R.: Evaluation of ACCMIP outgoing longwave radiation from tropospheric ozone using TES satellite observations, Atmos. Chem. Phys., 13, 40574072, doi:10.5194/acp-13-4057-2013, 2013.

Butchart, N.: The Brewer-Dobson circulation, Rev. Geophys., 52, 157-184, doi:10.1002/2013RG000448, 2014.

Butchart, N., Scaife, A. A., Bourqui, M., de Grandpré, J., Hare, S. H. E., Kettleborough, J., Langematz, U., Manzini, E., Sassi, F., Shibata, K., Shindell, D., and Sigmond, M.: Simulations of anthropogenic change in the strength of the Brewer-Dobson circulation, Clim. Dynam., 27, 727-741, doi:10.1007/s00382-0060162-4, 2006.

Butchart, N., Cionni, I., Eyring, V., Shepherd, T. G., Waugh, D. W., Akiyoshi, H., Austin, J., Brühl, C., Chipperfield, M. P., Cordero, E., Dameris, M., Deckert, R., Dhomse, S., Frith, S. M., Garcia, R. R., Gettelman, A., Giorgetta, M. A., Kinnison, D. E., Li, F., Mancini, E., McLandress, C., Pawson, S., Pitari, G., Plummer, D. A., Rozanov, E., Sassi, F., Scinocca, J. F., Shibata, K., Steil, B., and Tian, W.: Chemistry-Climate Model Simulations of TwentyFirst Century Stratospheric Climate and Circulation Changes, J. Climate, 23, 5349-5374, doi:10.1175/2010JCLI3404.1, 2010.

Butchart, N., Charlton-Perez, A. J., Cionni, I., Hardiman, S. C., Haynes, P. H., Krüger, K., Kushner, P. J., Newman, P. A., Osprey, S. M., Perlwitz, J., Sigmond, M., Wang, L., Akiyoshi, H., Austin, J., Bekki, S., Baumgaertner, A., Braesicke, P., Brühl, C., Chipperfield, M., Dameris, M., Dhomse, S., Eyring, V., Garcia, R., Garny, H., Jöckel, P., Lamarque, J. F., Marchand, M., Michou, M., Morgenstern, O., Nakamura, T., Pawson, S., Plummer, D., Pyle, J., Rozanov, E., Scinocca, J., Shepherd, T. G., Shibata, K., Smale, D., Teyssèdre, H., Tian, W., Waugh, D., and Yamashita, Y.: Multimodel climate and variability of the stratosphere, J. Geophys. Res., 116, D05102, doi:10.1029/2010JD014995, 2011.

Calvo, N., Garcia, R. R., Marsh, D. R., Mills, M. J., Kinnison, D. E., and Young, P. J.: Reconciling modeled and observed temperature trends over Antarctica, Geophys. Res. Lett., 39, L16803, doi:10.1029/2012g1052526, 2012.

Charlton-Perez, A. J., Hawkins, E., Eyring, V., Cionni, I., Bodeker, G. E., Kinnison, D. E., Akiyoshi, H., Frith, S. M., Garcia, R., Gettelman, A., Lamarque, J. F., Nakamura, T., Pawson, S., Yamashita, Y., Bekki, S., Braesicke, P., Chipperfield, M. P., Dhomse, S., Marchand, M., Mancini, E., Morgenstern, O., Pitari, G., Plummer, D., Pyle, J. A., Rozanov, E., Scinocca, J., Shibata, K., Shepherd, T. G., Tian, W., and Waugh, D. W.: The potential to narrow uncertainty in projections of stratospheric ozone over the 21st century, Atmos. Chem. Phys., 10, 94739486, doi:10.5194/acp-10-9473-2010, 2010.

Charlton-Perez, A. J., Baldwin, M. P., Birner, T., Black, R. X., Butler, A. H., Calvo, N., Davis, N. A., Gerber, E. P., Gillett, N., Hardiman, S., Kim, J., Krüger, K., Lee, Y.-Y., Manzini, E., McDaniel, B. A., Polvani, L., Reichler, T., Shaw, T. A., Sigmond,
M., Son, S.-W., Toohey, M., Wilcox, L., Yoden, S., Christiansen, B., Lott, F., Shindell, D., Yukimoto, S., and Watanabe, S.: On the lack of stratospheric dynamical variability in low-top versions of the CMIP5 models, J. Geophys. Res., 118, 2494-2505, doi:10.1002/jgrd.50125, 2013.

Christy, J. R., Spencer, R. W., Norris, W. B., Braswell, W. D., and Parker, D. E.: Error Estimates of Version 5.0 of MSU-AMSU Bulk Atmospheric Temperatures, J. Atmos. Ocean. Tech., 20, 613-629, doi:10.1175/15200426(2003)20<613:EEOVOM>2.0.CO;2, 2003.

Cionni, I., Eyring, V., Lamarque, J. F., Randel, W. J., Stevenson, D. S., Wu, F., Bodeker, G. E., Shepherd, T. G., Shindell, D. T., and Waugh, D. W.: Ozone database in support of CMIP5 simulations: results and corresponding radiative forcing, Atmos. Chem. Phys., 11, 11267-11292, doi:10.5194/acp-11-11267-2011, 2011.

Collins, W. J., Derwent, R. G., Garnier, B., Johnson, C. E., Sanderson, M. G., and Stevenson, D. S.: Effect of stratospheretroposphere exchange on the future tropospheric ozone trend, J. Geophys. Res., 108, 8528, doi:10.1029/2002JD002617, 2003.

Collins, W. J., Bellouin, N., Doutriaux-Boucher, M., Gedney, N., Halloran, P., Hinton, T., Hughes, J., Jones, C. D., Joshi, M., Liddicoat, S., Martin, G., O’Connor, F., Rae, J., Senior, C., Sitch, S., Totterdell, I., Wiltshire, A., and Woodward, S.: Development and evaluation of an Earth-System model - HadGEM2, Geosci. Model Dev., 4, 1051-1075, doi:10.5194/gmd-4-10512011, 2011.

Crook, J. A., Gillett, N. P., and Keeley, S. P. E.: Sensitivity of Southern Hemisphere climate to zonal asymmetry in ozone, Geophys. Res. Lett., 35, L07806, doi:10.1029/2007GL032698, 2008.

Dietmüller, S., Ponater, M., and Sausen, R.: Interactive ozone induces a negative feedback in $\mathrm{CO} 2$-driven climate change simulations, J. Geophys. Res., 119, 1796-1805, doi:10.1002/2013JD020575, 2014.

Donner, L. J., Wyman, B. L., Hemler, R. S., Horowitz, L. W., Ming, Y., Zhao, M., Golaz, J.-C., Ginoux, P., Lin, S. J., Schwarzkopf, M. D., Austin, J., Alaka, G., Cooke, W. F., Delworth, T. L., Freidenreich, S. M., Gordon, C. T., Griffies, S. M., Held, I. M., Hurlin, W. J., Klein, S. A., Knutson, T. R., Langenhorst, A. R., Lee, H.-C., Lin, Y., Magi, B. I., Malyshev, S. L., Milly, P. C. D., Naik, V., Nath, M. J., Pincus, R., Ploshay, J. J., Ramaswamy, V., Seman, C. J., Shevliakova, E., Sirutis, J. J., Stern, W. F., Stouffer, R. J., Wilson, R. J., Winton, M., Wittenberg, A. T., and Zeng, F.: The Dynamical Core, Physical Parameterizations, and Basic Simulation Characteristics of the Atmospheric Component AM3 of the GFDL Global Coupled Model CM3, J. Climate, 24, 34843519, doi:10.1175/2011JCLI3955.1, 2011.

Dvortsov, V. L. and Solomon, S.: Response of the stratospheric temperatures and ozone to past and future increases in stratospheric humidity, J. Geophys. Res., 106, 7505-7514, doi:10.1029/2000JD900637, 2001.

Engel, A., Mobius, T., Bonisch, H., Schmidt, U., Heinz, R., Levin, I., Atlas, E., Aoki, S., Nakazawa, T., Sugawara, S., Moore, F., Hurst, D., Elkins, J., Schauffler, S., Andrews, A., and Boering, K.: Age of stratospheric air unchanged within uncertainties over the past 30 years, Nature Geosci., 2, 28-31, doi:10.1038/ngeo388, 2009.

Eyring, V., Butchart, N., Waugh, D. W., Akiyoshi, H., Austin, J., Bekki, S., Bodeker, G. E., Boville, B. A., Brühl, C., Chipperfield, M. P., Cordero, E., Dameris, M., Deushi, M., Fioletov, V. 
E., Frith, S. M., Garcia, R. R., Gettelman, A., Giorgetta, M. A., Grewe, V., Jourdain, L., Kinnison, D. E., Mancini, E., Manzini, E., Marchand, M., Marsh, D. R., Nagashima, T., Newman, P. A., Nielsen, J. E., Pawson, S., Pitari, G., Plummer, D. A., Rozanov, E., Schraner, M., Shepherd, T. G., Shibata, K., Stolarski, R. S., Struthers, H., Tian, W., and Yoshiki, M.: Assessment of temperature, trace species, and ozone in chemistry-climate model simulations of the recent past, J. Geophys. Res., 111, D22308, doi:10.1029/2006JD007327, 2006.

Eyring, V., Waugh, D. W., Bodeker, G. E., Cordero, E., Akiyoshi, H., Austin, J., Beagley, S. R., Boville, B. A., Braesicke, P., Brühl, C., Butchart, N., Chipperfield, M. P., Dameris, M., Deckert, R., Deushi, M., Frith, S. M., Garcia, R. R., Gettelman, A., Giorgetta, M. A., Kinnison, D. E., Mancini, E., Manzini, E., Marsh, D. R., Matthes, S., Nagashima, T., Newman, P. A., Nielsen, J. E., Pawson, S., Pitari, G., Plummer, D. A., Rozanov, E., Schraner, M., Scinocca, J. F., Semeniuk, K., Shepherd, T. G., Shibata, K., Steil, B., Stolarski, R. S., Tian, W., and Yoshiki, M.: Multimodel projections of stratospheric ozone in the 21st century, J. Geophys. Res., 112, D16303, doi:10.1029/2006JD008332, 2007.

Eyring, V., Cionni, I., Bodeker, G. E., Charlton-Perez, A. J., Kinnison, D. E., Scinocca, J. F., Waugh, D. W., Akiyoshi, H., Bekki, S., Chipperfield, M. P., Dameris, M., Dhomse, S., Frith, S. M., Garny, H., Gettelman, A., Kubin, A., Langematz, U., Mancini, E., Marchand, M., Nakamura, T., Oman, L. D., Pawson, S., Pitari, G., Plummer, D. A., Rozanov, E., Shepherd, T. G., Shibata, K., Tian, W., Braesicke, P., Hardiman, S. C., Lamarque, J. F., Morgenstern, O., Pyle, J. A., Smale, D., and Yamashita, Y.: Multimodel assessment of stratospheric ozone return dates and ozone recovery in CCMVal-2 models, Atmos. Chem. Phys., 10, 94519472, doi:10.5194/acp-10-9451-2010, 2010a.

Eyring, V., Cionni, I., Lamarque, J. F., Akiyoshi, H., Bodeker, G. E., Charlton-Perez, A. J., Frith, S. M., Gettelman, A., Kinnison, D. E., Nakamura, T., Oman, L. D., Pawson, S., and Yamashita, Y.: Sensitivity of 21 st century stratospheric ozone to greenhouse gas scenarios, Geophys. Res. Lett., 37, L16807, doi:10.1029/2010GL044443, 2010b.

Eyring, V., Arblaster, J. M., Cionni, I., Sedláček, J., Perlwitz, J., Young, P. J., Bekki, S., Bergmann, D., Cameron-Smith, P., Collins, W. J., Faluvegi, G., Gottschaldt, K. D., Horowitz, L. W., Kinnison, D. E., Lamarque, J. F., Marsh, D. R., SaintMartin, D., Shindell, D. T., Sudo, K., Szopa, S., and Watanabe, S.: Long-term ozone changes and associated climate impacts in CMIP5 simulations, J. Geophys. Res., 118, 5029-5060, doi:10.1002/jgrd.50316, 2013.

Forster, P. M., Thompson, D. W. J. (Coordinating Lead Authors), Baldwin, M. P., Chipperfield, M. P., Dameris, M., Haigh, J. D., Karoly, D. J., Kushner, P. J., Randel, W. J., Rosenlof, K. H., Seidel, D. J., Solomon, S., Beig, G., Braesicke, P., Butchart, N., Gillett, N. P., Grise, K. M., Marsh, D. R., McLandress, C., Rao, T. N., Son, S.-W., Stenchikov, G. L., and Yoden, S.: Stratospheric changes and climate, Chapter 4 in Scientific Assessment of Ozone Depletion: 2010, Global Ozone Research and Monitoring Project-Report No. 52, 516 pp., Geneva, Switzerland, World Meteorological Organization, 2011.

Fu, Q., Solomon, S., and Lin, P.: On the seasonal dependence of tropical lower-stratospheric temperature trends, Atmos. Chem. Phys., 10, 2643-2653, doi:10.5194/acp-10-2643-2010, 2010.
Fyfe, J. C., Boer, G. J., and Flato, G. M.: The Arctic and Antarctic oscillations and their projected changes under global warming, Geophys. Res. Lett., 26, 1601-1604, doi:10.1029/1999GL900317, 1999.

Garcia, R. R. and Randel, W. J.: Acceleration of the Brewer-Dobson Circulation due to Increases in Greenhouse Gases, J. Atmos. Sci., 65, 2731-2739, doi:10.1175/2008JAS2712.1, 2008.

Gent, P., Yeager, S., Neale, R., Levis, S., and Bailey, D.: Improvements in a half degree atmosphere/land version of the CCSM, Clim. Dynam., 34, 819-833, doi:10.1007/s00382-009-0614-8, 2010.

Gillett, N. P. and Fyfe, J. C.: Annular mode changes in the CMIP5 simulations, Geophys. Res. Lett., 40, 1189-1193, doi:10.1002/grl.50249, 2013.

Gillett, N. P. and Thompson, D. W. J.: Simulation of Recent Southern Hemisphere Climate Change, Science, 302, 273-275, doi:10.1126/science.1087440, 2003.

Gillett, N. P., Scinocca, J. F., Plummer, D. A., and Reader, M. C.: Sensitivity of climate to dynamically-consistent zonal asymmetries in ozone, Geophys. Res. Lett., 36, L10809, doi:10.1029/2009GL037246, 2009.

Gillett, N. P., Akiyoshi, H., Bekki, S., Braesicke, P., Eyring, V., Garcia, R., Karpechko, A. Yu., McLinden, C. A., Morgenstern, O., Plummer, D. A., Pyle, J. A., Rozanov, E., Scinocca, J., and Shibata, K.: Attribution of observed changes in stratospheric ozone and temperature, Atmos. Chem. Phys., 11, 599609, doi:10.5194/acp-11-599-2011, 2011.

Gong, D. and Wang, S.: Definition of Antarctic Oscillation index, Geophys. Res. Lett., 26, 459-462, doi:10.1029/1999GL900003, 1999.

Gregg, J. W., Jones, C. G., and Dawson, T. E.: Urbanization effects on tree growth in the vicinity of New York City, Nature, 424, 183-187, doi:10.1038/nature01728, 2003.

Griffies, S. M., Winton, M., Donner, L. J., Horowitz, L. W., Downes, S. M., Farneti, R., Gnanadesikan, A., Hurlin, W. J., Lee, H.C., Liang, Z., Palter, J. B., Samuels, B. L., Wittenberg, A. T., Wyman, B. L., Yin, J., and Zadeh, N.: The GFDL CM3 Coupled Climate Model: Characteristics of the Ocean and Sea Ice Simulations, J. Climate, 24, 3520-3544, doi:10.1175/2011JCLI3964.1, 2011.

Grise, K. M., Thompson, D. W. J., and Forster, P. M.: On the Role of Radiative Processes in Stratosphere-Troposphere Coupling, J. Climate, 22, 4154-4161, doi:10.1175/2009JCLI2756.1, 2009.

Grytsai, A. V., Evtushevsky, O. M., Agapitov, O. V., Klekociuk, A. R., and Milinevsky, G. P.: Structure and long-term change in the zonal asymmetry in Antarctic total ozone during spring, Ann. Geophys., 25, 361-374, doi:10.5194/angeo-25-361-2007, 2007.

The HadGEM2 Development Team: G. M. Martin, Bellouin, N., Collins, W. J., Culverwell, I. D., Halloran, P. R., Hardiman, S. C., Hinton, T. J., Jones, C. D., McDonald, R. E., McLaren, A. J., O'Connor, F. M., Roberts, M. J., Rodriguez, J. M., Woodward, S., Best, M. J., Brooks, M. E., Brown, A. R., Butchart, N., Dearden, C., Derbyshire, S. H., Dharssi, I., Doutriaux-Boucher, M., Edwards, J. M., Falloon, P. D., Gedney, N., Gray, L. J., Hewitt, H. T., Hobson, M., Huddleston, M. R., Hughes, J., Ineson, S., Ingram, W. J., James, P. M., Johns, T. C., Johnson, C. E., Jones, A., Jones, C. P., Joshi, M. M., Keen, A. B., Liddicoat, S., Lock, A. P., Maidens, A. V., Manners, J. C., Milton, S. F., Rae, J. G. L., Ridley, J. K., Sellar, A., Senior, C. A., Totterdell, I. J., Verhoef, A., 
Vidale, P. L., and Wiltshire, A.: The HadGEM2 family of Met Office Unified Model climate configurations, Geosci. Model Dev., 4, 723-757, doi:10.5194/gmd-4-723-2011, 2011.

Haigh, J. D. and Pyle, J. A.: Ozone perturbation experiments in a two-dimensional circulation model, Q. J. Roy. Meteor. Soc., 108, 551-574, doi:10.1002/qj.49710845705, 1982.

Haimberger, L., Tavolato, C., and Sperka, S.: Toward Elimination of the Warm Bias in Historic Radiosonde Temperature Records - Some New Results from a Comprehensive Intercomparison of Upper-Air Data, J. Climate, 21, 4587-4606, doi:10.1175/2008JCLI1929.1, 2008.

Haimberger, L., Tavolato, C., and Sperka, S.: Homogenization of the Global Radiosonde Temperature Dataset through Combined Comparison with Reanalysis Background Series and Neighboring Stations, J. Climate, 25, 8108-8131, doi:10.1175/JCLI-D-11$00668.1,2012$.

Hassler, B., Young, P. J., Portmann, R. W., Bodeker, G. E., Daniel, J. S., Rosenlof, K. H., and Solomon, S.: Comparison of three vertically resolved ozone data sets: climatology, trends and radiative forcings, Atmos. Chem. Phys., 13, 5533-5550, doi:10.5194/acp13-5533-2013, 2013.

Holton, J. R., Haynes, P. H., McIntyre, M. E., Douglass, A. R., Rood, R. B., and Pfister, L.: Stratosphere-troposphere exchange, Rev. Geophys., 33, 403-439, doi:10.1029/95RG02097, 1995.

Hsu, J. and Prather, M. J.: Stratospheric variability and tropospheric ozone, J. Geophys. Res., 114, D06102, doi:10.1029/2008JD010942, 2009.

IPCC: Climate Change 2013: The Physical Science Basis. Contribution of Working Group I to the Fifth Assessment Report of the Intergovernmental Panel on Climate Change, Cambridge University Press, Cambridge, United Kingdom and New York, NY, USA, 1535 pp., 2013.

Isaksen, I. S. A., Granier, C., Myhre, G., Berntsen, T. K., Dalsøren, S. B., Gauss, M., Klimont, Z., Benestad, R., Bousquet, P., Collins, W., Cox, T., Eyring, V., Fowler, D., Fuzzi, S., Jöckel, P., Laj, P., Lohmann, U., Maione, M., Monks, P., Prevot, A. S. H., Raes, F., Richter, A., Rognerud, B., Schulz, M., Shindell, D., Stevenson, D. S., Storelvmo, T., Wang, W. C., van Weele, M., Wild, M., and Wuebbles, D.: Atmospheric composition change: Climate-Chemistry interactions, Atmos. Environ., 43, 5138-5192, doi:10.1016/j.atmosenv.2009.08.003, 2009.

Jacob, D. J. and Winner, D. A.: Effect of climate change on air quality, Atmos. Environ., 43, 51-63, doi:10.1016/j.atmosenv.2008.09.051, 2009.

Jerrett, M., Burnett, R. T., Pope, C. A., Ito, K., Thurston, G., Krewski, D., Shi, Y., Calle, E., and Thun, M.: Long-Term Ozone Exposure and Mortality, New Engl. J. Med., 360, 1085-1095, doi:10.1056/NEJMoa0803894, 2009.

Keeble, J., Braesicke, P., Abraham, N. L., Roscoe, H. K., and Pyle, J. A.: The impact of polar stratospheric ozone loss on Southern Hemisphere stratospheric circulation and climate, Atmos. Chem. Phys., 14, 13705-13717, doi:10.5194/acp-14-13705-2014, 2014.

Koch, D., Schmidt, G. A., and Field, C. V.: Sulfur, sea salt, and radionuclide aerosols in GISS ModelE, J. Geophys. Res., 111, D06206, doi:10.1029/2004JD005550, 2006.

Lamarque, J.-F. and Solomon, S.: Impact of Changes in Climate and Halocarbons on Recent Lower Stratosphere Ozone and Temperature Trends, J. Climate, 23, 2599-2611, doi:10.1175/2010JCLI3179.1, 2010.
Lamarque, J.-F., Kyle, G. P., Meinshausen, M., Riahi, K., Smith, S., van Vuuren, D., Conley, A., and Vitt, F.: Global and regional evolution of short-lived radiatively-active gases and aerosols in the Representative Concentration Pathways, Clim. Change, 109, 191-212, doi:10.1007/s10584-011-0155-0, 2011.

Lamarque, J.-F., Emmons, L. K., Hess, P. G., Kinnison, D. E., Tilmes, S., Vitt, F., Heald, C. L., Holland, E. A., Lauritzen, P. H., Neu, J., Orlando, J. J., Rasch, P. J., and Tyndall, G. K.: CAM-chem: description and evaluation of interactive atmospheric chemistry in the Community Earth System Model, Geosci. Model Dev., 5, 369-411, doi:10.5194/gmd-5-369-2012, 2012.

Lamarque, J.-F., Dentener, F., McConnell, J., Ro, C.-U., Shaw, M., Vet, R., Bergmann, D., Cameron-Smith, P., Dalsoren, S., Doherty, R., Faluvegi, G., Ghan, S. J., Josse, B., Lee, Y. H., MacKenzie, I. A., Plummer, D., Shindell, D. T., Skeie, R. B., Stevenson, D. S., Strode, S., Zeng, G., Curran, M., Dahl-Jensen, D., Das, S., Fritzsche, D., and Nolan, M.: Multi-model mean nitrogen and sulfur deposition from the Atmospheric Chemistry and Climate Model Intercomparison Project (ACCMIP): evaluation of historical and projected future changes, Atmos. Chem Phys., 13, 7997-8018, doi:10.5194/acp-13-7997-2013, $2013 \mathrm{a}$.

Lamarque, J.-F., Shindell, D. T., Josse, B., Young, P. J., Cionni, I., Eyring, V., Bergmann, D., Cameron-Smith, P., Collins, W. J., Doherty, R., Dalsoren, S., Faluvegi, G., Folberth, G., Ghan, S. J., Horowitz, L. W., Lee, Y. H., MacKenzie, I. A., Nagashima, T., Naik, V., Plummer, D., Righi, M., Rumbold, S. T., Schulz, M., Skeie, R. B., Stevenson, D. S., Strode, S., Sudo, K., Szopa, S., Voulgarakis, A., and Zeng, G.: The Atmospheric Chemistry and Climate Model Intercomparison Project (ACCMIP): overview and description of models, simulations and climate diagnostics, Geosci. Model Dev., 6, 179-206, doi:10.5194/gmd-6-179-2013, 2013b.

Lary, D. J.: Catalytic destruction of stratospheric ozone, J. Geophys. Res., 102, 21515-21526, 1997.

Lee, Y. H., Lamarque, J.-F., Flanner, M. G., Jiao, C., Shindell, D. T., Berntsen, T., Bisiaux, M. M., Cao, J., Collins, W. J., Curran, M., Edwards, R., Faluvegi, G., Ghan, S., Horowitz, L. W., McConnell, J. R., Ming, J., Myhre, G., Nagashima, T., Naik, V., Rumbold, S. T., Skeie, R. B., Sudo, K., Takemura, T., Thevenon, F., Xu, B., and Yoon, J.-H.: Evaluation of preindustrial to presentday black carbon and its albedo forcing from Atmospheric Chemistry and Climate Model Intercomparison Project (ACCMIP), Atmos. Chem. Phys., 13, 2607-2634, doi:10.5194/acp13-2607-2013, 2013.

Lelieveld, J. and Dentener, F. J.: What controls tropospheric ozone?, J. Geophys. Res., 105, 3531-3551, doi:10.1029/1999JD901011, 2000.

Marshall, G. J.: Trends in the Southern Annular Mode from Observations and Reanalyses, J. Climate, 16, 4134-4143, doi:10.1175/1520-0442(2003)016<4134:TITSAM>2.0.CO;2, 2003.

Marshall, G. J.: Half-century seasonal relationships between the Southern Annular mode and Antarctic temperatures, Int. J. Climatol., 27, 373-383, doi:10.1002/joc.1407, 2007.

Marshall, G. J., Stott, P. A., Turner, J., Connolley, W. M., King, J. C., and Lachlan-Cope, T. A.: Causes of exceptional atmospheric circulation changes in the Southern Hemisphere, Geophys. Res. Lett., 31, L14205, doi:10.1029/2004GL019952, 2004. 
McLandress, C., Shepherd, T. G., Scinocca, J. F., Plummer, D. A., Sigmond, M., Jonsson, A. I., and Reader, M. C.: Separating the Dynamical Effects of Climate Change and Ozone Depletion. Part II: Southern Hemisphere Troposphere, J. Climate, 24, 18501868, doi:10.1175/2010JCLI3958.1, 2011.

McLinden, C. A., Olsen, S. C., Hannegan, B., Wild, O., Prather, M. J., and Sundet, J.: Stratospheric ozone in 3-D models: A simple chemistry and the cross-tropopause flux, J. Geophys. Res., 105, 14653-14665, doi:10.1029/2000JD900124, 2000.

McPeters, R. D., Bhartia, P. K., Haffner, D., Labow, G. J., and Flynn, L.: The version 8.6 SBUV ozone data record: An overview, J. Geophys. Res., 118, 8032-8039, doi:10.1002/jgrd.50597, 2013.

Mears, C. A., Wentz, F. J., Thorne, P., and Bernie, D.: Assessing uncertainty in estimates of atmospheric temperature changes from MSU and AMSU using a Monte-Carlo estimation technique, J. Geophys. Res., 116, D08112, doi:10.1029/2010JD014954, 2011.

Meinshausen, M., Smith, S. J., Calvin, K., Daniel, J. S., Kainuma, M. L. T., Lamarque, J. F., Matsumoto, K., Montzka, S. A., Raper, S. C. B., Riahi, K., Thomson, A., Velders, G. J. M., and Vuuren, D. P. P.: The RCP greenhouse gas concentrations and their extensions from 1765 to 2300, Clim. Change, 109, 213-241, doi:10.1007/s10584-011-0156-z, 2011.

Meul, S., Langematz, U., Oberländer, S., Garny, H., and Jöckel, P.: Chemical contribution to future tropical ozone change in the lower stratosphere, Atmos. Chem. Phys., 14, 2959-2971, doi:10.5194/acp-14-2959-2014, 2014.

Morgenstern, O., Akiyoshi, H., Bekki, S., Braesicke, P., Butchart, N., Chipperfield, M. P., Cugnet, D., Deushi, M., Dhomse, S. S., Garcia, R. R., Gettelman, A., Gillett, N. P., Hardiman, S. C., Jumelet, J., Kinnison, D. E., Lamarque, J. F., Lott, F., Marchand, M., Michou, M., Nakamura, T., Olivié, D., Peter, T., Plummer, D., Pyle, J. A., Rozanov, E., Saint-Martin, D., Scinocca, J. F., Shibata, K., Sigmond, M., Smale, D., Teyssèdre, H., Tian, W., Voldoire, A., and Yamashita, Y.: Anthropogenic forcing of the Northern Annular Mode in CCMVal-2 models, J. Geophys. Res., 115, D00M03, doi:10.1029/2009JD013347, 2010a.

Morgenstern, O., Giorgetta, M. A., Shibata, K., Eyring, V., Waugh, D. W., Shepherd, T. G., Akiyoshi, H., Austin, J., Baumgaertner, A. J. G., Bekki, S., Braesicke, P., Brühl, C., Chipperfield, M. P., Cugnet, D., Dameris, M., Dhomse, S., Frith, S. M., Garny, H., Gettelman, A., Hardiman, S. C., Hegglin, M. I., Jöckel, P., Kinnison, D. E., Lamarque, J. F., Mancini, E., Manzini, E., Marchand, M., Michou, M., Nakamura, T., Nielsen, J. E., Olivié, D., Pitari, G., Plummer, D. A., Rozanov, E., Scinocca, J. F., Smale, D., Teyssèdre, H., Toohey, M., Tian, W., and Yamashita, Y.: Review of the formulation of present-generation stratospheric chemistryclimate models and associated external forcings, J. Geophys. Res., 115, D00M02, doi:10.1029/2009JD013728, 2010b.

Myhre, G., Shindell, D., Brè̀on, F.-M., Collins, W., Fuglestvedt, J., Huang, J., Koch, D., Lamarque, J.-F., Lee, D., Mendoza, B., Nakajima, T., Robock, A., Stephens, G., Takemura, T., and Zhang, H.: Anthropogenic and Natural Radiative Forcing, in: Climate Change 2013: The Physical Science Basis. Contribution of Working Group I to the Fifth Assessment Report of the Intergovernmental Panel on Climate Change, edited by: Stocker, T. F., Qin, D., Plattner, G.-K., Tignor, M., Allen, S. K., Boschung, J., Nauels, A., Xia, Y., Bex, V., and Midgley, P. M., Cambridge
University Press, Cambridge, United Kingdom and New York, NY, USA, 659-740, 2013.

Naik, V., Horowitz, L. W., Fiore, A. M., Ginoux, P., Mao, J., Aghedo, A. M., and Levy, H.: Impact of preindustrial to presentday changes in short-lived pollutant emissions on atmospheric composition and climate forcing, J. Geophys. Res., 118, 80868110, doi:10.1002/jgrd.50608, 2013a.

Naik, V., Voulgarakis, A., Fiore, A. M., Horowitz, L. W., Lamarque, J.-F., Lin, M., Prather, M. J., Young, P. J., Bergmann, D., Cameron-Smith, P. J., Cionni, I., Collins, W. J., Dalsøren, S. B., Doherty, R., Eyring, V., Faluvegi, G., Folberth, G. A., Josse, B., Lee, Y. H., MacKenzie, I. A., Nagashima, T., van Noije, T. P. C., Plummer, D. A., Righi, M., Rumbold, S. T., Skeie, R., Shindell, D. T., Stevenson, D. S., Strode, S., Sudo, K., Szopa, S., and Zeng, G.: Preindustrial to present-day changes in tropospheric hydroxyl radical and methane lifetime from the Atmospheric Chemistry and Climate Model Intercomparison Project (ACCMIP), Atmos. Chem. Phys., 13, 5277-5298, doi:10.5194/acp-13-5277-2013, 2013b.

Newman, P. A., Nash, E. R., and Rosenfield, J. E.: What controls the temperature of the Arctic stratosphere during the spring?, J. Geophys. Res., 106, 19999-20010, doi:10.1029/2000JD000061, 2001.

Nowack, P. J., Luke Abraham, N., Maycock, A. C., Braesicke, P., Gregory, J. M., Joshi, M. M., Osprey, A., and Pyle, J. A.: A large ozone-circulation feedback and its implications for global warming assessments, Nature Clim. Change, 5, 41-45, doi:10.1038/nclimate2451, 2015.

Parrish, D. D., Lamarque, J. F., Naik, V., Horowitz, L., Shindell, D. T., Staehelin, J., Derwent, R., Cooper, O. R., Tanimoto, H., Volz-Thomas, A., Gilge, S., Scheel, H. E., Steinbacher, M., and Fröhlich, M.: Long-term changes in lower tropospheric baseline ozone concentrations: Comparing chemistry-climate models and observations at northern midlatitudes, J. Geophys. Res., 119, 5719-5736, doi:10.1002/2013JD021435, 2014.

Perlwitz, J.: Atmospheric science: Tug of war on the jet stream, Nature Clim. Change, 1, 29-31, doi:10.1038/nclimate1065, 2011.

Perlwitz, J., Pawson, S., Fogt, R. L., Nielsen, J. E., and Neff, W. D.: Impact of stratospheric ozone hole recovery on Antarctic climate, Geophys. Res. Lett., 35, L08714, doi:10.1029/2008GL033317, 2008.

Polvani, L. M. and Solomon, S.: The signature of ozone depletion on tropical temperature trends, as revealed by their seasonal cycle in model integrations with single forcings, J. Geophys. Res., 117, D17102, doi:10.1029/2012JD017719, 2012.

Polvani, L. M., Waugh, D. W., Correa, G. J. P., and Son, S.-W.: Stratospheric Ozone Depletion: The Main Driver of Twentieth-Century Atmospheric Circulation Changes in the Southern Hemisphere, J. Climate, 24, 795-812, doi:10.1175/2010JCLI3772.1, 2010.

Polvani, L. M., Previdi, M., and Deser, C.: Large cancellation, due to ozone recovery, of future Southern Hemisphere atmospheric circulation trends, Geophys. Res. Lett., 38, L04707, doi:10.1029/2011GL046712, 2011.

Portmann, R. W. and Solomon, S.: Indirect radiative forcing of the ozone layer during the 21st century, Geophys. Res. Lett., 34, L02813, doi:10.1029/2006GL028252, 2007.

Portmann, R. W., Daniel, J. S., and Ravishankara, A. R.: Stratospheric ozone depletion due to nitrous oxide: influences 
of other gases, Philos. T. Roy. Soc. B, 367, 1256-1264, doi:10.1098/rstb.2011.0377, 2012.

Prather, M. J., Ehhalt, D., Houghton, J. T., Ding, Y., and Griggs, D. J. (Eds.): Atmospheric Chemistry and Greenhouse Gases, in: Climate Change 2001: The Scientific Basis, Cambridge University Press, Cambridge, UK, 239-287, 2001.

Previdi, M. and Polvani, L. M.: Climate system response to stratospheric ozone depletion and recovery, Q. J. Roy. Meteor. Soc., 140, 2401-2419, doi:10.1002/qj.2330, 2014.

Ramaswamy, V., Schwarzkopf, M. D., Randel, W. J., Santer, B. D., Soden, B. J., and Stenchikov, G. L.: Anthropogenic and Natural Influences in the Evolution of Lower Stratospheric Cooling, Science, 311, 1138-1141, doi:10.1126/science.1122587, 2006.

Randel, W. J. and Wu, F.: Cooling of the Arctic and Antarctic Polar Stratospheres due to Ozone Depletion, J. Climate, 12, 1467-1479, doi:10.1175/15200442(1999)012<1467:COTAAA>2.0.CO;2, 1999.

Randel, W. J., Park, M., Wu, F., and Livesey, N.: A Large Annual Cycle in Ozone above the Tropical Tropopause Linked to the Brewer-Dobson Circulation, J. Atmos. Sci., 64, 4479-4488, doi:10.1175/2007JAS2409.1, 2007.

Randel, W. J., Shine, K. P., Austin, J., Barnett, J., Claud, C., Gillett, N. P., Keckhut, P., Langematz, U., Lin, R., Long, C., Mears, C., Miller, A., Nash, J., Seidel, D. J., Thompson, D. W. J., Wu, F., and Yoden, S.: An update of observed stratospheric temperature trends, J. Geophys. Res., 114, D02107, doi:10.1029/2008JD010421, 2009.

Randeniya, L. K., Vohralik, P. F., and Plumb, I. C.: Stratospheric ozone depletion at northern mid latitudes in the 21st century: The importance of future concentrations of greenhouse gases nitrous oxide and methane, Geophys. Res. Lett., 29, 10-11-10-14, doi:10.1029/2001GL014295, 2002.

Ravishankara, A. R., Daniel, J. S., and Portmann, R. W.: Nitrous Oxide $\left(\mathrm{N}_{2} \mathrm{O}\right)$ : The Dominant Ozone-Depleting Substance Emitted in the 21st Century, Science, 326, 123-125, doi:10.1126/science.1176985, 2009.

Reader, M. C., Plummer, D. A., Scinocca, J. F., and Shepherd, T. G.: Contributions to twentieth century total column ozone change from halocarbons, tropospheric ozone precursors, and climate change, Geophys. Res. Lett., 40, 6276-6281, doi:10.1002/2013GL057776, 2013.

Revell, L. E., Bodeker, G. E., Smale, D., Lehmann, R., Huck, P. E., Williamson, B. E., Rozanov, E., and Struthers, H.: The effectiveness of N2O in depleting stratospheric ozone, Geophys. Res. Lett., 39, L15806, doi:10.1029/2012GL052143, 2012.

Rosenfield, J. E., Douglass, A. R., and Considine, D. B.: The impact of increasing carbon dioxide on ozone recovery, J. Geophys. Res., 107, ACH 7-1-ACH 7-9, doi:10.1029/2001JD000824, 2002

Santer, B. D., Wigley, T. M. L., Boyle, J. S., Gaffen, D. J., Hnilo, J. J., Nychka, D., Parker, D. E., and Taylor, K. E.: Statistical significance of trends and trend differences in layer-average atmospheric temperature time series, J. Geophys. Res., 105, 73377356, doi:10.1029/1999JD901105, 2000.

Santer, B. D., Sausen, R., Wigley, T. M. L., Boyle, J. S., AchutaRao, K., Doutriaux, C., Hansen, J. E., Meehl, G. A., Roeckner, E., Ruedy, R., Schmidt, G., and Taylor, K. E.: Behavior of tropopause height and atmospheric temperature in models, re- analyses, and observations: Decadal changes, J. Geophys. Res., 108, 4002, doi:10.1029/2002JD002258, 2003a.

Santer, B. D., Wehner, M. F., Wigley, T. M. L., Sausen, R., Meehl, G. A., Taylor, K. E., Ammann, C., Arblaster, J., Washington, W. M., Boyle, J. S., and Brüggemann, W.: Contributions of Anthropogenic and Natural Forcing to Recent Tropopause Height Changes, Science, 301, 479-483, doi:10.1126/science.1084123, 2003b.

Schmidt, G. A., Ruedy, R., Hansen, J. E., Aleinov, I., Bell, N., Bauer, M., Bauer, S., Cairns, B., Canuto, V., Cheng, Y., Del Genio, A., Faluvegi, G., Friend, A. D., Hall, T. M., Hu, Y., Kelley, M., Kiang, N. Y., Koch, D., Lacis, A. A., Lerner, J., Lo, K. K., Miller, R. L., Nazarenko, L., Oinas, V., Perlwitz, J., Perlwitz, J., Rind, D., Romanou, A., Russell, G. L., Sato, M., Shindell, D. T., Stone, P. H., Sun, S., Tausnev, N., Thresher, D., and Yao, M.S.: Present-Day Atmospheric Simulations Using GISS ModelE: Comparison to In Situ, Satellite, and Reanalysis Data, J. Climate, 19, 153-192, doi:10.1175/JCLI3612.1, 2006.

Scinocca, J. F., McFarlane, N. A., Lazare, M., Li, J., and Plummer, D.: Technical Note: The CCCma third generation AGCM and its extension into the middle atmosphere, Atmos. Chem. Phys., 8, 7055-7074, doi:10.5194/acp-8-7055-2008, 2008.

Sexton, D. M. H.: The effect of stratospheric ozone depletion on the phase of the Antarctic Oscillation, Geophys. Res. Lett., 28, 3697-3700, doi:10.1029/2001GL013376, 2001.

Shepherd, T. G.: Dynamics, stratospheric ozone, and climate change, Atmos.-Ocean, 46, 117-138, doi:10.3137/ao.460106, 2008.

Shepherd, T. G., Plummer, D. A., Scinocca, J. F., Hegglin, M. I., Fioletov, V. E., Reader, M. C., Remsberg, E., von Clarmann, T., and Wang, H. J.: Reconciliation of halogen-induced ozone loss with the total-column ozone record, Nature Geosci., 7, 443-449, doi:10.1038/ngeo2155, 2014.

Sherwood, S. C., Meyer, C. L., Allen, R. J., and Titchner, H. A.: Robust Tropospheric Warming Revealed by Iteratively Homogenized Radiosonde Data, J. Climate, 21, 5336-5352, doi:10.1175/2008JCLI2320.1, 2008.

Shindell, D. T. and Schmidt, G. A.: Southern Hemisphere climate response to ozone changes and greenhouse gas increases, Geophys. Res. Lett., 31, L18209, doi:10.1029/2004GL020724, 2004.

Shindell, D. T., Faluvegi, G., Stevenson, D. S., Krol, M. C., Emmons, L. K., Lamarque, J. F., Pétron, G., Dentener, F. J., Ellingsen, K., Schultz, M. G., Wild, O., Amann, M., Atherton, C. S., Bergmann, D. J., Bey, I., Butler, T., Cofala, J., Collins, W. J., Derwent, R. G., Doherty, R. M., Drevet, J., Eskes, H. J., Fiore, A. M., Gauss, M., Hauglustaine, D. A., Horowitz, L. W., Isaksen, I. S. A., Lawrence, M. G., Montanaro, V., Müller, J. F., Pitari, G., Prather, M. J., Pyle, J. A., Rast, S., Rodriguez, J. M., Sanderson, M. G., Savage, N. H., Strahan, S. E., Sudo, K., Szopa, S., Unger, N., van Noije, T. P. C., and Zeng, G.: Multimodel simulations of carbon monoxide: Comparison with observations and projected near-future changes, J. Geophys. Res., 111, D19306, doi:10.1029/2006JD007100, 2006.

Shindell, D. T., Lamarque, J.-F., Schulz, M., Flanner, M., Jiao, C., Chin, M., Young, P. J., Lee, Y. H., Rotstayn, L., Mahowald, N., Milly, G., Faluvegi, G., Balkanski, Y., Collins, W. J., Conley, A. J., Dalsoren, S., Easter, R., Ghan, S., Horowitz, L., Liu, X., Myhre, G., Nagashima, T., Naik, V., Rumbold, S. T., Skeie, R., Sudo, K., Szopa, S., Takemura, T., Voulgarakis, A., Yoon, J.-H., 
and Lo, F.: Radiative forcing in the ACCMIP historical and future climate simulations, Atmos. Chem. Phys., 13, 2939-2974, doi:10.5194/acp-13-2939-2013, 2013a.

Shindell, D. T., Pechony, O., Voulgarakis, A., Faluvegi, G., Nazarenko, L., Lamarque, J.-F., Bowman, K., Milly, G., Kovari, B., Ruedy, R., and Schmidt, G. A.: Interactive ozone and methane chemistry in GISS-E2 historical and future climate simulations, Atmos. Chem. Phys., 13, 2653-2689, doi:10.5194/acp-13-26532013, 2013b.

Solomon, S., Young, P. J., and Hassler, B.: Uncertainties in the evolution of stratospheric ozone and implications for recent temperature changes in the tropical lower stratosphere, Geophys. Res. Lett., 39, L17706, doi:10.1029/2012g1052723, 2012.

Son, S.-W., Tandon, N. F., Polvani, L. M., and Waugh, D. W.: Ozone hole and Southern Hemisphere climate change, Geophys. Res. Lett., 36, L15705, doi:10.1029/2009GL038671, 2009.

Son, S. W., Polvani, L. M., Waugh, D. W., Akiyoshi, H., Garcia, R., Kinnison, D., Pawson, S., Rozanov, E., Shepherd, T. G., and Shibata, K.: The Impact of Stratospheric Ozone Recovery on the Southern Hemisphere Westerly Jet, Science, 320, 1486-1489, doi:10.1126/science.1155939, 2008.

Son, S. W., Gerber, E. P., Perlwitz, J., Polvani, L. M., Gillett, N. P., Seo, K. H., Eyring, V., Shepherd, T. G., Waugh, D., Akiyoshi, H., Austin, J., Baumgaertner, A., Bekki, S., Braesicke, P., Brühl, C., Butchart, N., Chipperfield, M. P., Cugnet, D., Dameris, M., Dhomse, S., Frith, S., Garny, H., Garcia, R., Hardiman, S. C., Jöckel, P., Lamarque, J. F., Mancini, E., Marchand, M., Michou, M., Nakamura, T., Morgenstern, O., Pitari, G., Plummer, D. A., Pyle, J., Rozanov, E., Scinocca, J. F., Shibata, K., Smale, D., Teyssèdre, H., Tian, W., and Yamashita, Y.: Impact of stratospheric ozone on Southern Hemisphere circulation change: A multimodel assessment, J. Geophys. Res., 115, D00M07, doi:10.1029/2010JD014271, 2010.

SPARC CCMVal: SPARC CCMVal Report on the Evaluation of Chemistry-Climate Models, edited by: Eyring, V., Shepherd, T. G., and Waugh, D. W., SPARC Report No. 5, WCRP-132, WMO/TD-No. 1526, 2010.

Stevenson, D. S.: Atmospheric chemistry: Climate's chemical sensitivity, Nature Clim. Change, 5, 21-22, doi:10.1038/nclimate2477, 2015.

Stevenson, D. S., Dentener, F. J., Schultz, M. G., Ellingsen, K., van Noije, T. P. C., Wild, O., Zeng, G., Amann, M., Atherton, C. S., Bell, N., Bergmann, D. J., Bey, I., Butler, T., Cofala, J., Collins, W. J., Derwent, R. G., Doherty, R. M., Drevet, J., Eskes, H. J., Fiore, A. M., Gauss, M., Hauglustaine, D. A., Horowitz, L. W., Isaksen, I. S. A., Krol, M. C., Lamarque, J. F., Lawrence, M. G., Montanaro, V., Müller, J. F., Pitari, G., Prather, M. J., Pyle, J. A., Rast, S., Rodriguez, J. M., Sanderson, M. G., Savage, N. H., Shindell, D. T., Strahan, S. E., Sudo, K., and Szopa, S.: Multimodel ensemble simulations of present-day and near-future tropospheric ozone, J. Geophys. Res., 111, D08301, doi:10.1029/2005JD006338, 2006.

Stevenson, D. S., Young, P. J., Naik, V., Lamarque, J.-F., Shindell, D. T., Voulgarakis, A., Skeie, R. B., Dalsoren, S. B., Myhre, G., Berntsen, T. K., Folberth, G. A., Rumbold, S. T., Collins, W. J., MacKenzie, I. A., Doherty, R. M., Zeng, G., van Noije, T. P. C., Strunk, A., Bergmann, D., Cameron-Smith, P., Plummer, D. A., Strode, S. A., Horowitz, L., Lee, Y. H., Szopa, S., Sudo, K., Nagashima, T., Josse, B., Cionni, I., Righi, M., Eyring, V., Conley,
A., Bowman, K. W., Wild, O., and Archibald, A.: Tropospheric ozone changes, radiative forcing and attribution to emissions in the Atmospheric Chemistry and Climate Model Intercomparison Project (ACCMIP), Atmos. Chem. Phys., 13, 3063-3085, doi:10.5194/acp-13-3063-2013, 2013.

Stiller, G. P., von Clarmann, T., Haenel, F., Funke, B., Glatthor, N., Grabowski, U., Kellmann, S., Kiefer, M., Linden, A., Lossow, S., and López-Puertas, M.: Observed temporal evolution of global mean age of stratospheric air for the 2002 to 2010 period, Atmos. Chem. Phys., 12, 3311-3331, doi:10.5194/acp-12-33112012, 2012.

Struthers, H., Bodeker, G. E., Austin, J., Bekki, S., Cionni, I., Dameris, M., Giorgetta, M. A., Grewe, V., Lefèvre, F., Lott, F., Manzini, E., Peter, T., Rozanov, E., and Schraner, M.: The simulation of the Antarctic ozone hole by chemistry-climate models, Atmos. Chem. Phys., 9, 6363-6376, doi:10.5194/acp-9-63632009, 2009.

Sudo, K., Takahashi, M., and Akimoto, H.: Future changes in stratosphere-troposphere exchange and their impacts on future tropospheric ozone simulations, Geophys. Res. Lett., 30, 2256, doi:10.1029/2003GL018526, 2003.

Taylor, K. E., Stouffer, R. J., and Meehl, G. A.: An Overview of CMIP5 and the Experiment Design, B. Am. Meteorol. Soc., 93, 485-498, doi:10.1175/BAMS-D-11-00094.1, 2012.

Thompson, D. W. J. and Solomon, S.: Interpretation of Recent Southern Hemisphere Climate Change, Science, 296, 895-899, doi:10.1126/science.1069270, 2002.

Thompson, D. W. J. and Wallace, J. M.: Annular Modes in the Extratropical Circulation. Part I: Month-to-Month Variability, J. Climate, 13, 1000-1016, doi:10.1175/15200442(2000)013<1000:AMITEC>2.0.CO;2, 2000.

Thompson, D. W. J., Solomon, S., Kushner, P. J., England, M. H., Grise, K. M., and Karoly, D. J.: Signatures of the Antarctic ozone hole in Southern Hemisphere surface climate change, Nature Geosci., 4, 741-749, doi:10.1038/ngeo1296, 2011.

Thorne, P. W., Parker, D. E., Tett, S. F. B., Jones, P. D., McCarthy, M., Coleman, H., and Brohan, P.: Revisiting radiosonde upper air temperatures from 1958 to 2002, J. Geophys. Res., 110, D18105, doi:10.1029/2004JD005753, 2005.

UNEP: Environmental effects of ozone depletion and its interaction with climate change: 2015 assessment, United Nations Environment Programme (UNEP), Nairobi, 2015.

van Vuuren, Detlef, P., Edmonds, J., Kainuma, M., Riahi, K., Thomson, A., Hibbard, K., Hurtt, G., Kram, T., Krey, V., Lamarque, J.-F., Masui, T., Meinshausen, M., Nakicenovic, N., Smith, S., and Rose, S.: The representative concentration pathways: an overview, Clim. Change, 109, 5-31, doi:10.1007/s10584-0110148-z, 2011.

Voulgarakis, A., Naik, V., Lamarque, J.-F., Shindell, D. T., Young, P. J., Prather, M. J., Wild, O., Field, R. D., Bergmann, D., CameronSmith, P., Cionni, I., Collins, W. J., Dalsøren, S. B., Doherty, R. M., Eyring, V., Faluvegi, G., Folberth, G. A., Horowitz, L. W., Josse, B., MacKenzie, I. A., Nagashima, T., Plummer, D. A., Righi, M., Rumbold, S. T., Stevenson, D. S., Strode, S. A., Sudo, K., Szopa, S., and Zeng, G.: Analysis of present day and future $\mathrm{OH}$ and methane lifetime in the ACCMIP simulations, Atmos. Chem. Phys., 13, 2563-2587, doi:10.5194/acp-13-25632013, 2013. 
Watanabe, S., Hajima, T., Sudo, K., Nagashima, T., Takemura, T., Okajima, H., Nozawa, T., Kawase, H., Abe, M., Yokohata, T., Ise, T., Sato, H., Kato, E., Takata, K., Emori, S., and Kawamiya, M.: MIROC-ESM 2010: model description and basic results of CMIP5-20c3m experiments, Geosci. Model Dev., 4, 845-872, doi:10.5194/gmd-4-845-2011, 2011.

Waugh, D. W., Oman, L., Kawa, S. R., Stolarski, R. S., Pawson, S., Douglass, A. R., Newman, P. A., and Nielsen, J. E.: Impacts of climate change on stratospheric ozone recovery, Geophys. Res. Lett., 36, L03805, doi:10.1029/2008GL036223, 2009a.

Waugh, D. W., Oman, L., Newman, P. A., Stolarski, R. S., Pawson, S., Nielsen, J. E., and Perlwitz, J.: Effect of zonal asymmetries in stratospheric ozone on simulated Southern Hemisphere climate trends, Geophys. Res. Lett., 36, L18701, doi:10.1029/2009GL040419, 2009b.

Wilcox, L. J., Charlton-Perez, A. J., and Gray, L. J.: Trends in Austral jet position in ensembles of high- and low-top CMIP5 models, J. Geophys. Res., 117, D13115, doi:10.1029/2012JD017597, 2012.

Wild, O.: Modelling the global tropospheric ozone budget: exploring the variability in current models, Atmos. Chem. Phys., 7, 2643-2660, doi:10.5194/acp-7-2643-2007, 2007.

WMO: Scientific Assessment of Ozone Depletion: 2006, World Meteorological Organization, Geneva, Switzerland, 572 pp., 2007.

WMO: Scientific Assessment of Ozone Depletion: 2010, World Meteorological Organization, Geneva, Switzerland, 516 pp., 2011.

WMO: Scientific Assessment of Ozone Depletion: 2014, World Meteorological Organization, Global Ozone Research and Monitoring Project, Geneva, Switzerland, 2014.

Young, P. J., Rosenlof, K. H., Solomon, S., Sherwood, S. C., Fu, Q., and Lamarque, J. F.: Changes in Stratospheric Temperatures and Their Implications for Changes in the BrewerDobson Circulation, 1979-2005, J. Climate, 25, 1759-1772, doi:10.1175/2011jcli4048.1, 2011.

Young, P. J., Archibald, A. T., Bowman, K. W., Lamarque, J.-F., Naik, V., Stevenson, D. S., Tilmes, S., Voulgarakis, A., Wild, O., Bergmann, D., Cameron-Smith, P., Cionni, I., Collins, W. J., Dalsøren, S. B., Doherty, R. M., Eyring, V., Faluvegi, G., Horowitz, L. W., Josse, B., Lee, Y. H., MacKenzie, I. A., Nagashima, T., Plummer, D. A., Righi, M., Rumbold, S. T., Skeie, R. B., Shindell, D. T., Strode, S. A., Sudo, K., Szopa, S., and Zeng, G.: Preindustrial to end 21 st century projections of tropospheric ozone from the Atmospheric Chemistry and Climate Model Intercomparison Project (ACCMIP), Atmos. Chem. Phys., 13, 20632090, doi:10.5194/acp-13-2063-2013, 2013a.
Young, P. J., Butler, A. H., Calvo, N., Haimberger, L., Kushner, P. J., Marsh, D. R., Randel, W. J., and Rosenlof, K. H.: Agreement in late twentieth century Southern Hemisphere stratospheric temperature trends in observations and CCMVal-2, CMIP3, and CMIP5 models, J. Geophys. Res., 118, 605-613, doi:10.1002/jgrd.50126, 2013b.

Young, P. J., Davis, S. M., Hassler, B., Solomon, S., and Rosenlof, K. H.: Modeling the climate impact of Southern Hemisphere ozone depletion: The importance of the ozone data set, Geophys. Res. Lett., 41, 9033-9039, doi:10.1002/2014GL061738, 2014.

Zeng, G. and Pyle, J. A.: Changes in tropospheric ozone between 2000 and 2100 modeled in a chemistry-climate model, Geophys. Res. Lett., 30, 1392, doi:10.1029/2002GL016708, 2003.

Zeng, G., Pyle, J. A., and Young, P. J.: Impact of climate change on tropospheric ozone and its global budgets, Atmos. Chem. Phys., 8, 369-387, doi:10.5194/acp-8-369-2008, 2008.

Zeng, G., Morgenstern, O., Braesicke, P., and Pyle, J. A.: Impact of stratospheric ozone recovery on tropospheric ozone and its budget, Geophys. Res. Lett., 37, L09805, doi:10.1029/2010GL042812, 2010.

Zou, C.-Z., Goldberg, M. D., Cheng, Z., Grody, N. C., Sullivan, J. T., Cao, C., and Tarpley, D.: Recalibration of microwave sounding unit for climate studies using simultaneous nadir overpasses, J. Geophys. Res., 111, D19114, doi:10.1029/2005JD006798, 2006.

Zou, C.-Z., Gao, M., and Goldberg, M. D.: Error Structure and Atmospheric Temperature Trends in Observations from the Microwave Sounding Unit, J. Climate, 22, 1661-1681, doi:10.1175/2008JCLI2233.1, 2009. 